\title{
Lamba Parlaklığı Konusunda Değişkenleri Belirleme ve Kontrol Etmenin Öğretiminde Analoji Kullanımının Etkisi"
}

\section{The Effect of the Using Analogy on The Teaching of Identifying and Controlling Variables on the Brightness of a Bulb}

\author{
Gonca HARMAN**
}

\author{
Aytekin ÇÖKELEZ ${ }^{* * *}$ iD
}

Received: 25 March 2018

Research Article

Accepted: 15 January 2019

ABSTRACT: This study investigated the effect of the using analogy on the teaching of identifying and controlling variables on the brightness of a bulb. The study was conducted with the participation of 98 fifth grade students. 49 students were in the experimental group and 49 students were in the control group. The unmatched control group pretest and posttest method was used in this study, interviews were done with the students. Analogy was used in the experimental group and analogy was not used in the control group in the implementation process. A data collection form consisting of two questions was used in this study. In the first question, the students were asked to choose two circuits that they could see the effect of the battery's number on the bulb's brightness from four simple electrical circuits. In the second question, the students were asked to choose two circuits that they could see the effect of the bulb's number on the bulb's brightness from four simple electrical circuits. Data were analyzed using content analysis. As a result of the research, it has been found that the using of analogy is effective on the learning and elimination of misconceptions. Teaching with analogy is focused interest and attention on the issue, made the lesson fun. It is thought that these situations have an effect on the result.

Keywords: analogy, identifying and controlling variables, brightness of a bulb, fifth grade student.

ÖZ: $\mathrm{Bu}$ araştırmada lamba parlaklığı konusunda değişkenleri belirleme ve kontrol etmenin öğretiminde analoji kullanımının öğrenme ve kavram yanılgılarının giderilmesi üzerindeki etkisi incelenmiştir. Araştırmaya ortaokul beşinci sınıfta öğrenim görmekte olan 98 öğrenci katılmıştır. 49 öğrenci deney, 49 öğrenci kontrol grubunda yer almıştır. Araştırmada yarı deneysel yöntem çeşitlerinden eşitlenmemiş kontrol gruplu ön ve son test yöntemi kullanılmış, yarı yapılandırılmış görüşmeler yapılmıştır. Deney grubunda analoji kullanılarak, kontrol grubunda ise analoji kullanılmadan ders işlenmiştir. Araştırmada iki sorudan oluşan bir veri toplama aracı kullanılmıştır. Birinci soruda öğrencilerden dört basit elektrik devresi içinden pil sayısının lamba parlaklığı üzerindeki etkisini görebilecekleri iki devre seçmeleri istenmiştir. İkinci soruda öğrencilerden dört basit elektrik devresi içinden lamba sayısının lamba parlaklığı üzerindeki etkisini görebilecekleri iki devre seçmeleri istenmiştir. Veriler içerik analizi ile çözümlenmiştir. Araştırma sonucunda analoji kullanımının öğrenme ve kavram yanılgılarının giderilmesi üzerinde etkili olduğu saptanmıştır. Bu sonuç üzerinde analoji ile gerçekleştirilen öğretimin ilgi ve dikkatleri konu üzerinde yoğunlaştırmasının, dersi eğlenceli hale getirmesinin etkili olduğu düşünülmektedir.

Anahtar kelimeler: analoji, değişkenleri belirleme ve kontrol etme, lamba parlaklığı, beşinci sınıf öğrencisi.

\footnotetext{
${ }^{*}$ This research was supported by OMU Project Management Office (Project No: PYO.EGF.1904.13.006). This study is a part of the first author's doctorate thesis.

** Corresponding Author: Dr., drgoncaharman@ @otmail.com

**** Prof. Dr., Istanbul Technical University, Istanbul, Turkey, cokelez@itu.edu.tr
}

Harman, G., \& Çökelez, A. (2019). Lamba parlaklığı konusunda değişkenleri belirleme ve kontrol etmenin öğretiminde analoji kullanımının etkisi. Kuramsal Eğitimbilim Dergisi [Journal of Theoretical Educational Science], 12(1), 369-400. 


\section{Giriş}

Bilimsel süreç becerileri öğrenme ortamında öğrencinin aktifleşmesini sağlayan, öğrenciye öğrenme sorumluluğu ve araştırma yeteneği kazandıran, öğrenmeyi kolaylaştıran ve kalıcı hale getiren becerilerdir. $\mathrm{Bu}$ beceriler temel, nedensel ve deneysel olmak üzere üçe ayrılır. Temel beceriler: gözlem yapma, ölçme, sınıflama, verileri kaydetme, sayı ve uzay ilişkisi kurma; nedensel beceriler: önceden kestirme, değişkenleri belirleme, sonuç çıkarma (yordama); deneysel beceriler: hipotez kurma, model oluşturma, deney yapma, değişkenleri değiştirme ve kontrol etme ile karar vermedir (Akdeniz, 2011).

Bilim insanlarının bilgi üretirken kullandıkları yöntemlerin fen öğretimine bir yansıması olan bu beceriler bilimsel okuryazar toplumlarda farklı meslek gruplarındaki bireylerin sahip olması ve kullanması gereken, yaşamın her alanında uygulanabilecek süreçleri kapsamaktadır. Yaşamda karşılaşılan olayları anlamak, anlamlandırmak, öğrenilen bilgilerle ilişki kurmak, bilimsel okuryazar bir birey olmak için bilimsel süreç becerileri kullanılmalıdır. Laboratuvarda, derslerde ve yaşamda olaylara bilim insanı gibi bakan, araştıran, sorgulayan, yaratıcı düşünceler üreten bireyler yetiştirilebilmesi için bu becerilerin kazandırılması ve geliştirilmesi gereklidir (Temiz \& Tan, 2009).

Bilimsel süreç becerilerini kazanan bireyler olaylara daha geniş bir bakış açısı ile bakarak karşılaştıkları problemleri kolayca çözebilirler (Güden \& Timur, 2016). Bilimsel süreç becerileri bilgiye ulaşmada, günlük yaşamdaki olayları sorgulamada ve araştırma yapmada, eleştirel düşünmede, problemleri bilimsel yollarla çözmede, karar verme becerilerini geliştirmede bireylere kolaylık sağlarlar (Karar \& Yenice, 2012). Bilimsel süreç becerilerinin okulda, iş yerinde ve günlük yaşamda oldukça önemli bir yeri vardır (Şen \& Nakiboğlu, 2012). Bununla birlikte fen okuryazarı bireyler yetiştirmek için bilimsel süreç becerileri kazandırılmalı ve geliştirilmelidir (BostanSarığlan, Gedik \& Can, 2016). Bu becerilerin kazandırılmasında ve geliştirilmesinde öğrencilerin erken yaşlardan itibaren deneyim kazanmaya başlamaları son derece önemlidir (Durmaz \& Mutlu, 2012). Bu nedenle okul öncesinden başlanarak bilimsel süreç becerileri öğretilmeli ve ölçülerek değerlendirilmelidir (Temiz \& Tan, 2009).

Bilimsel süreç becerilerinden biri olan değişkenleri belirleme hem fen ve fizik derslerinde hem de yaşamın her alanında kullanılmaktadır (Temiz \& Tan, 2009). Değişkenleri belirleme becerisi bir durum ya da olay üzerinde etkili olan bütün faktörleri saptamayı ve farklı koşullarda değişen veya sabit kalan faktörlerin özelliklerini tanımayı içermektedir. Araştırma sürecinde bir olay üzerinde etkili olan değişkenleri belirlemek ve bu değişkenleri test etmek çok önemlidir (Akdeniz, 2011). Bir sonuç üzerinde etkili olan çok sayıda değişken olabilir. Sonucun nedenini anlamak ya da yapılacak herhangi bir değişikliğin sonuç üzerinde oluşturacağı etkileri görmek için söz konusu değişken dişındaki değişkenlerin belirlenmesi ve deney düzeneğinin buna uygun olarak kurulması gereklidir. Bundan ötürü deneylerde değişkenleri belirlemek, kontrol edilmesi ya da sabit tutulması gereken unsurları tanımlamak son derece önemlidir (Bozkurt \& Olgun, 2005). Ancak alanyazın incelendiğinde ortaokul öğrencilerinin (Anagün \& Yaşar, 2009; Ayas-Kör, 2006; Böyük, Tanık, \& Saraçoğlu, 2011; Durmaz \& Mutlu, 2012; Keser \& Başak, 2013; Ocak \& Tümer, 2014), 13-16 yaş aralığındaki öğrencilerin (Griffiths \& Thompson, 1993), lise 1. sınıf öğrencilerinin (Temiz \& Tan, 2009), 2. sınıfta (Bağcı-Kılıç, Yardımc1, \& Metin, 2009), 3. sınıfta 
(Ateş, 2005; Ateş \& Bahar, 2002), son sınıfta öğrenim gören sınıf öğretmeni adaylarının (Laçin-Şimşek, 2010), son sınıf fen bilgisi öğretmen adaylarının (Aydoğdu, 2012; Harman \& Çökelez, 2016), son sınıf fen ve teknoloji, sınıf ve biyoloji öğretmen adaylarının (Saka, 2012) bağımlı, bağımsız ve kontrol edilen olmak üzere farklı değişken türlerini birbiri ile karıştırdıkları, birbirinin yerine kullandıkları ve değişkenleri belirleme becerilerinin yetersiz olduğu görülmektedir. $\mathrm{Bu}$ sonuç beraberinde öğrencilerin hangi değişkeni değiştirip hangi değişken ya da değişkenleri sabit tutmaları gerektiğine karar verirken de bilimsel açıdan doğru olmayan cevaplar vermelerine neden olacaktır. Alanyazındaki araştırmalarda ortaya koyulan sonuçlar değişkenleri belirleme ve kontrol etmenin öğretiminde dikkat çekici öğretim araçları ile ilgi çekici ve eğlenceli etkinlikler yapılmasının gerekli olduğunu vurgulamaktadır. Bu öğretim araçlarından biri de analojilerdir.

Analojiler; kavram, ilke ve formüllerin benzerlikleri arasında kurulan sağlam bağlantılardır. Bu bağlantılar, ön bilgiler (kaynak) ile yeni bilgiler (hedef) arasında kurulan güçlü köprülerdir (Kesercioğlu, Yılmaz, Huyugüzel-Çavaş, \& Çavaş, 2004). Bilginin yapılandırılma sürecini kolaylaştıran, kavramsal değişimi anlaşılır kılan, kavramsal değişimle bireye yeni bakış açıları kazandıran, konu ile gerçek dünya arasındaki benzerliklere dikkat çekerek soyut anlamayı kolaylaştıran, kavramları görselleştiren, bireyin ilgisini çeken ve bireyi motive eden analojiler öğretimde kullanılabilecek güçlü araçlardır (Duit, 1991). Belleği yapılandırarak yeni bilgiler için hazır hale getiren analojiler (Gentner, 1983) hedef kavramın etki alanlarını bilindik kılarak öğrenmeyi kolaylaştırırlar. Bunların yanı sıra analojiler ön bilgilerin ve kavram yanılgılarının saptanmasında da etkilidir (Duit, 1991). Bu nedenle araştırmada lamba parlaklığı konusunda değişkenleri belirleme ve kontrol etmenin öğretiminde analoji kullanımının etkilerinin incelenmesi amaçlanmıştır.

\section{Yöntem}

\section{Çalışmanın Türü}

Araştırmada yarı deneysel desen çeşitlerinden eşitlenmemiş kontrol gruplu ön ve son test desen kullanılmıştır. Öğrencilerin düşüncelerini ayrıntılı bir şekilde ortaya koymak ve daha detaylı bilgi elde etmek için veri toplama aracındaki sorular deney ve kontrol gruplarında yer alan beşer öğrenciye yöneltilerek bu öğrencilerle bireysel olarak yarı yapılandırılmış görüşmeler yapılmıştır.

\section{Çalışma Grubu}

Araştırmanın çalışma grubunu 2013-2014 eğitim-öğretim yılı ikinci döneminde MEB'na bağlı bir devlet okulunda 5. sınıfta öğrenim görmekte olan 98 öğrenci oluşturmaktadır. Tablo 1'de deney ve kontrol gruplarında yer alan öğrencilerin cinsiyetlerine ait frekans dağglımı görülmektedir. 
Tablo 1

Deney ve Kontrol Gruplarında Yer Alan Öğrencilerin Cinsiyetleri için Frekans Dă̆glımı

\begin{tabular}{lccc}
\hline & Erkek öğrenci & Kız öğrenci & Toplam \\
\hline Deney grubu & 20 & 29 & 49 \\
Kontrol grubu & 25 & 24 & 49 \\
Toplam & 45 & 53 & 98 \\
\hline
\end{tabular}

\section{Uygulama}

Pilot uygulama. Deney grubu ile yapılacak gerçek uygulama öncesinde 25 beşinci sınıf öğrencisi ile pilot uygulama yapılmıştır. Deney ve kontrol grupları ile yapılan uygulamalarda araştırmacı tarafından yapılan bilgilendirmelerle aynı öğretmen tarafından dersler yürütülmüştür. Araştırmacı deney ve kontrol gruplarının tüm derslerinde gözlemci olarak yer almıştır. Her dersten önce öğretmenle gerçekleştirilecek uygulama hakkında 15-20 dakikalık bir ön çalışma yapılmıştır.

Deney grubu ile yapılan uygulama. Deney grubunda yer alan 49 öğrenci ile 11 ders saati süresince PSM 1-2-3 ile BED 1-2-3 arasında karşılaştırmalar yapılarak lamba parlaklığının nelere bağlı olduğu, pil sayısı ve lamba sayısının lamba parlaklığı üzerindeki etkisi, bağımlı, bağımsız ve kontrol edilen değişkenlerin öğretimine yönelik uygulama yapılmıştır.

Öğrencilere Pnömatik Sistem Modelindeki (PSM) (Harman \& Çökelez, 2015) (Şekil 1) elemanların basit elektrik devresinde (Şekil 2) hangi devre elemanına karşılık geldiği sorulmuştur.

Şekil 1. Pnömatik Sistem Modeli (PSM) Şekil 2. Basit Elektrik Devresi (BED)
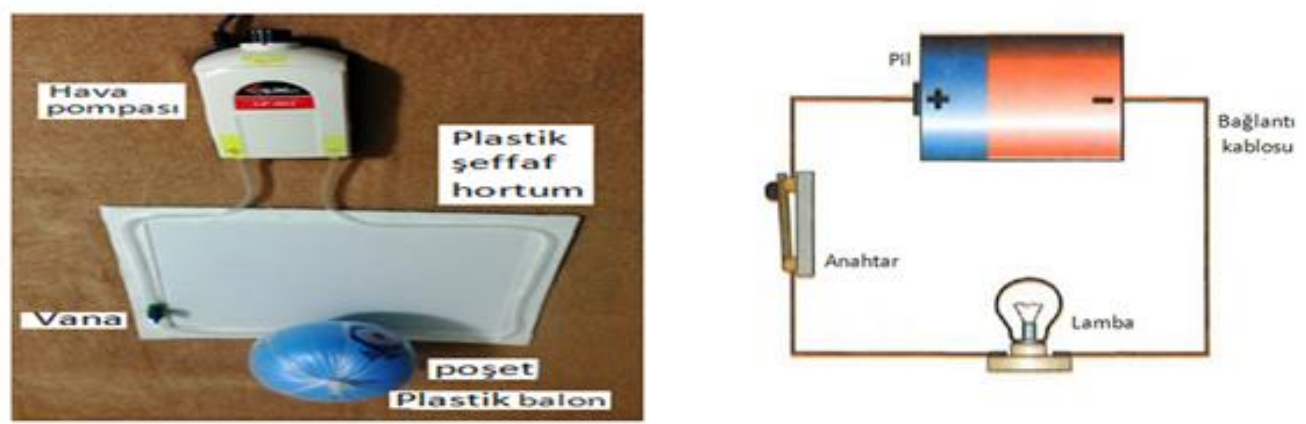

Tablo 2'de verilen PSM ve basit elektrik devresi için kaynak ve hedef kavramlar arasındaki analojik ilişki öncelikle öğrenciler, daha sonra da öğretmen tarafindan ifade edilmiştir. 
Tablo 2

Kaynak ve Hedef Kavramlar Arasındaki Analojik İlişki

\begin{tabular}{ll}
\hline Kaynak Kavramlar & Hedef Kavramlar \\
\hline Hava pompası & Pil \\
Plastik şeffaf hortum & Bağlantı kablosu \\
Vana & Anahtar \\
Plastik balon & Lamba \\
Plastik balonun şişmesi & Lambanın yanması \\
Plastik balonun şişme büyüklüğü & Lambanın parlaklığı \\
\hline
\end{tabular}

Analojilerde kaynak kavramlar ile hedef kavramlar arasında benzerlikler olduğu gibi farklılıklar da olabilir. Kaynak kavramlar ile hedef kavramlar arasındaki farklılıkların öğrencilerde konuya ilişkin kavram yanılgısı oluşmaması için ifade edilmesi gereklidir (Duit, 1991; Kesercioğlu ve diğerleri, 2004). Bu gereklilik dikkate alınarak ögretim sırasında kaynak kavramlar ile hedef kavramlar arasındaki farklılıklar belirtilmiştir. Basit elektrik devresinde elektrik akımı pile geri dönerken PSM'de hava pompasından çıkan hava pompaya geri dönmez. Basit elektrik devresinde lambanın yanması için pil devrede bağlı ve çalışır olmalıdır. PSM'de ise sistemi sabitlemek için hava pompası belirli bir süre sonunda durdurulmalıdır. Basit elektrik devresinde lambanın yanması için anahtar kapalı, PSM'de plastik balonun şişmesi için vana açık olmalıdır. Hava pompasından yayılan hava tek bir yol izleyerek plastik balona girerken bir plastik balondan diğerine hava geçişi olmaz. Basit elektrik devresinde ise lambalar arasında bir lambadan diğerine akım geçer (Harman \& Çökelez, 2015).

Deney grubunda pil sayısının lamba parlaklığı üzerindeki etkisinin öğretimi sırasında gerçekleştirilen etkinlikler: Pil sayısının lamba parlaklığı üzerindeki etkisini göstermek için PSM 1 ve PSM 2 kurulmuş ve çalıştırılmıştır. PSM 1 ve PSM 2 arasındaki farklılıklar öğrenciler tarafindan gözlemlenmiştir. PSM 1'de sisteme bir balon bağlanmış ve hava pompası birinci devirde çalıştırılmıştır. PSM 2'de sisteme bir balon bağlanmış, ancak hava pompası ikinci devirde çalıştırılmıştır. PSM 1 ve PSM 2'de eşit süre çalıştırılan hava pompası süre bitince durdurulmuştur. Öğrencilerden balonların şişme büyüklüklerini PSM 1 ile PSM 2'yi karşılaştırarak ifade etmeleri istenmiştir. Öğrencilerden PSM 1 ve PSM 2'de yer alan balonların şişme büyüklüklerinin neden farklı olduğunu açıklamaları istenmiştir. Öğrencilerden PSM 1 ve PSM 2 tarafından temsil edilen basit elektrik devrelerini (BED) çizmeleri istenmiştir. Öğrencilerin PSM 1 ve PSM 2 ile bu modellere karşılık gelen BED 1 ve BED 2 arasında analojik ilişki kurmaları sağlanmıştır. Öğrencilerden PSM ve BED' ler için balon büyüklüğü ve lamba parlaklığının hangi durumlarda azalacağını hangi durumlarda artacağını ifade etmeleri istenmiştir. 
Şekil 3. Pil Sayısının Lamba Parlaklığı Üzerindeki Etkisinin Öğretiminde Kullanılan PSM 1-2 ile BED 1-2

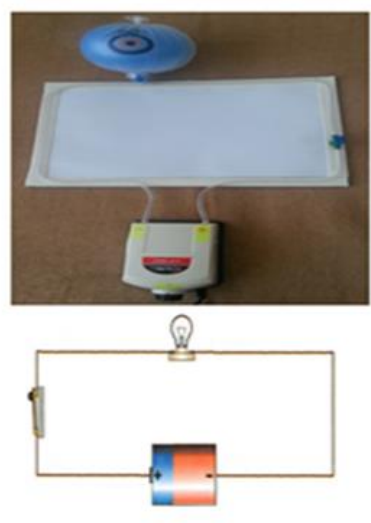

PSM 1 ve BED 1

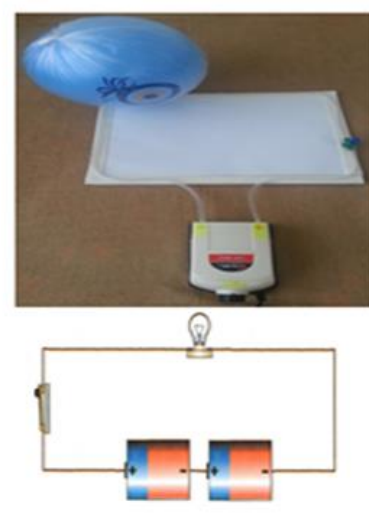

PSM 2 ve BED 2

Lamba parlaklığını etkileyen kavramlar hakkında balon sayıs1-lamba sayısı ve hava pompasının çalıştırıldığı devir-pil sayısı bağlamında sonuç çıkarılmıştır. Şekil 3'te görüldügü üzere balon sayısı (lamba sayısı) sabit olmak koşulu ile hava pompasının çalışma devrini (pil sayısı) arttırdığımız zaman balonun şişme büyüklüğü (lamba parlaklığı) artar. Balon sayısı (lamba sayısı) sabit olmak koşulu ile hava pompasının çalışma devrini (pil sayısı) azalttığımız zaman balonun şişme büyüklüğü (lamba parlaklığı) azalır.

Deney grubunda lamba sayısının lamba parlaklı̆̆ üzerindeki etkisinin öğretimi sırasında gerçekleştirilen etkinlikler: Lamba sayısının lamba parlaklığı üzerindeki etkisini göstermek için PSM 2 ve PSM 3 kurulmuş ve çalıştırılmıştır. PSM 2 ve PSM 3 arasındaki farklılıklar öğrenciler tarafından gözlemlenmiştir. PSM 2'de sisteme bir balon bağlanmış ve hava pompası ikinci devirde çalıştırılmıştır. PSM 3'te sisteme iki balon bağlanmış, hava pompası ikinci devirde çalıştırılmıştır. Hava pompası PSM 2 ve PSM 3'te eşit süre çalıştırılmış ve süre sonunda hava pompası durdurulmuştur. Öğrencilerden balonların şişme büyüklüklerini PSM 2 ile PSM 3 'ü karşılaştırarak ifade etmeleri istenmiştir. Öğrencilerden PSM 2 ve PSM 3'te yer alan balonların şişme büyüklüklerinin neden farklı olduğunu açıklamaları istenmiştir. Öğrencilerden PSM 2 ve PSM 3 tarafından temsil edilen basit elektrik devrelerini (BED) çizmeleri istenmiştir. Öğrencilerin PSM 2 ve PSM 3 ile bu modellere karşılık gelen BED 2 ve BED 3 arasında analojik ilişki kurmaları sağlanmıştır. Öğrencilerden PSM ve BED’ ler için balon büyüklüğü ve lamba parlaklığının hangi durumlarda azalacağını hangi durumlarda artacağını ifade etmeleri istenmiştir. 
Şekil 4. Lamba sayısının lamba parlaklığı üzerindeki etkisinin öğretiminde kullanılan PSM 2-3 ile BED 2-3

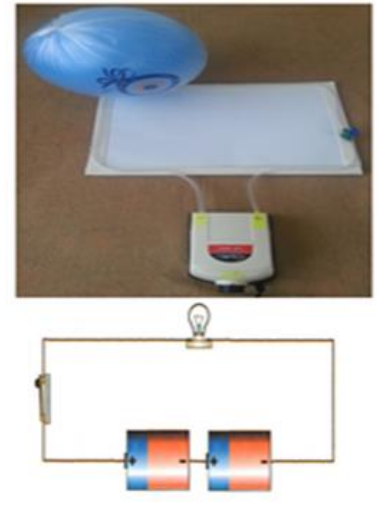

PSM 2 ve BED 2

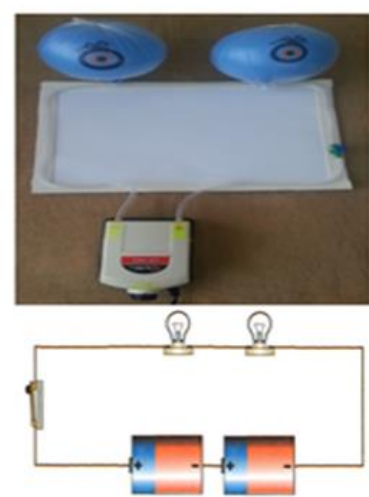

PSM 3 ve BED 3

Lamba parlaklığını etkileyen kavramlar hakkında balon sayısı-lamba sayısı ve hava pompasının çalıştırıldığı devir-pil sayısı bağlamında sonuç çıkarılmıştır. Şekil 4'te görüldüğü üzere hava pompasının çalışma devri (pil sayısı) sabit olmak koşulu ile balon sayısını (lamba sayısı) arttırdığımız zaman balonun şişme büyüklügü (lamba parlaklığı) azalır. Hava pompasının çalışma devri (pil sayısı) sabit olmak koşulu ile balon sayısını (lamba sayısı) azalttığımız zaman balonun şişme büyüklüğü (lamba parlaklığı) artar.

Deney grubunda bağıml, bă̆ımsız ve kontrol edilen değişkenlerin öğretimi sırasında gerçekleştirilen etkinlikler: Öğrencilere bağımlı, bağımsız ve kontrol edilen değişken kavramlarının anlamı açıklanmıştır. Şekil 5'teki PSM 1-2-3 ile BED 1-2-3'ü incelemeleri, PSM 1-PSM 2, PSM 2-PSM 3, BED 1-BED 2 ve BED 2-BED 3 arasinda karşılaştırmalar yapmaları, bağımlı, bağımsız ve kontrol edilen değişkenleri ifade etmeleri istenmiştir. Daha sonra öğretmen bağımlı, bağımsız ve kontrol edilen değişken kavramlarını Tablo 3'te görüldüğü şekilde ifade etmiştir. PSM 1'de hava pompası devir 1'de, PSM 2 ve PSM 3'te ise hava pompası devir 2'de (seri bağlı 2 pili temsilen) çalıştırılmıştır.

Şekil 5. Bağımlı, Bağımsız ve Kontrol Edilen Değişkenlerin Öğretiminde Kullanılan PSM 1-2-3 ile BED 1-2-3

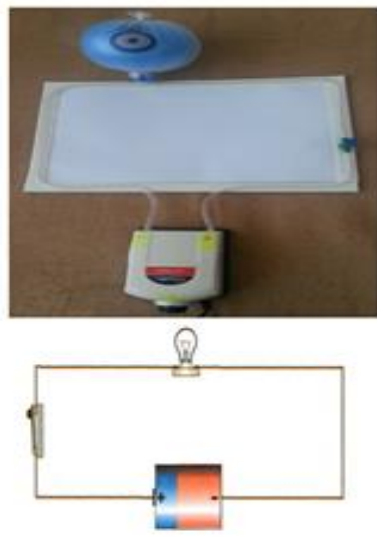

PSM 1 ve BED 1

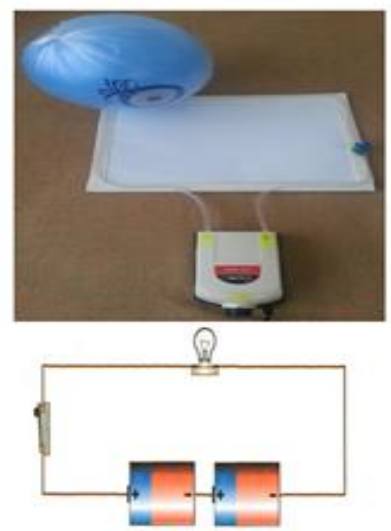

PSM 2 ve BED 2

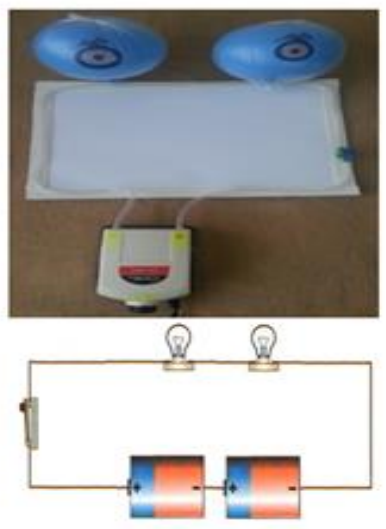

PSM 3 ve BED 3 
Tablo 3

Pnömatik Sistem Modeli (PSM) ve Basit Elektrik Devresi (BED) için Değişken Türleri

\begin{tabular}{lll}
\hline Değişken türü & PSM 1-PSM 2 (BED 1-BED 2) & PSM 2-PSM 3 (BED 2-BED 3) \\
\hline Bağımsız & hava pompasının çalıştırıldığı devir & plastik balon sayısı \\
& (pil sayısı) & (lamba sayısı) \\
Kontrol edilen & plastik balon sayısı & hava pompasının çalıştırıldığı devir \\
& (lamba sayısı) & (pil sayısı) \\
Bağımlı & plastik balonun şişme büyüklüğü & plastik balonun şişme büyüklüğü \\
& (lamba parlaklığı) & (lamba parlaklığı)
\end{tabular}

Kontrol grubu ile yapılan uygulama. Kontrol grubunda öğretim programı dikkate alınarak Pnömatik Sistem Modeli olarak adlandırılan analoji kullanılmadan ders işlenmiştir.

Kontrol grubunda pil sayısının lamba parlaklı̆̆ üzerindeki etkisinin öğretimi sırasında gerçekleştirilen etkinlikler: Pil sayısının lamba parlaklığı üzerindeki etkisini göstermek amacı ile BED 1 ve BED 2 kurulmuş ve çalıştırılmıştır. BED 1 ve BED 2 arasındaki farklılıklar öğrenciler tarafından gözlemlenmiştir. BED 1'de devreye bir pil ve bir lamba, BED 2'de devreye iki pil ve bir lamba bağlanmıştır. Öğrencilerden iki devreyi karşılaştırarak devrelerdeki lambanın parlaklıklarını ifade etmeleri istenmiştir. Öğrencilerden BED 1 ve BED 2'deki lambaların parlaklıklarının farklı olma nedenlerini açıklamaları istenmiştir. Öğrencilerden basit elektrik devrelerini (BED 1 ve BED 2) çizmeleri istenmiştir. Öğrencilerden BED 1 ve BED 2 için lamba parlaklığının hangi durumlarda azalacağını hangi durumlarda artacağını ifade etmeleri istenmiştir.

Lamba parlaklığını etkileyen kavramlar hakkında lamba sayısı ve pil sayısı bağlamında sonuç çıkarılmıştır. Lamba sayısı sabit olmak koşulu ile pil sayısını arttırdığımız zaman lambanın parlaklığı artar. Lamba sayısı sabit olmak koşulu ile pil sayısını azalttığımız zaman lambanın parlaklığı azalır.

Kontrol grubunda lamba sayısının lamba parlaklı̆̆ı üzerindeki etkisinin öğretimi sırasında gerçekleştirilen etkinlikler: Lamba sayısının lamba parlaklığı üzerindeki etkisini göstermek amacı ile BED 2 ve BED 3 kurulmuş ve çalıştırılmıştır. BED 2 ve BED 3 arasındaki benzerlikler ve farklılıklar öğrenciler tarafından gözlemlenmiştir. BED 2'de devreye iki pil ve bir lamba, BED 3'te devreye iki pil ve iki lamba bağlanmıştır. Öğrencilerden iki devreyi karşılaştırarak devrelerdeki lambanın parlaklıklarını ifade etmeleri istenmiştir. Öğrencilerden BED 2 ve BED 3'te lamba parlaklıklarının farklı olma nedenlerini açıklamaları istenmiştir. Öğrencilerden basit elektrik devrelerini (BED 2 ve BED 3) çizmeleri istenmiştir. Öğrencilerden BED 2 ve BED 3 için lamba parlaklığının hangi durumlarda azalacağını hangi durumlarda artacağını ifade etmeleri istenmiştir.

Lamba parlaklığını etkileyen kavramlar hakkında lamba sayısı ve pil sayısı bağlamında sonuç çıkarılmıştır. Pil sayısı sabit olmak koşulu ile lamba sayısını arttırdığımız zaman lambanın parlaklığı azalır. Pil sayısı sabit olmak koşulu ile lamba sayısını azalttığımız zaman lambanın parlaklığı artar. 
Kontrol grubunda bă̆ımlı, bă̆ımsız ve kontrol edilen değişkenlerin öğretimi sırasında gerçekleştirilen etkinlikler: Öğrencilere bağımlı, bağımsız ve kontrol edilen değişken kavramlarının anlamı açıklanmıştır. Öğrencilerden BED 1-2-3'ü incelemeleri, bu devrelerdeki değişkenleri belirlemeleri, bağımlı, bağımsız ve kontrol edilen değişkenleri BED 1-BED 2 ve BED 2-BED 3 arasında karşılaştırmalar yaparak ifade etmeleri istenmiştir. Daha sonra öğretmen BED 1-2-3 için bağıml, bağımsız ve kontrol edilen değişkenleri ifade etmiştir.

\section{Veri Toplama Araci}

Öğretim programı ile ulusal ve uluslararası alanyazın incelenerek iki sorudan oluşan bir veri toplama aracı hazırlanmıştır. Veri toplama aracında yer alan ifadelerin kapsam geçerliliği ile öğrencilerin konuyla ilgili bilgilerini belirleme yeterliliği, gereksiz, düzeltilmesi gereken ya da anlaşılmayan bir ifade olup olmadığı, öğrenci düzeyi ve ulaşılması hedeflenen kazanımlara uygun olup olmadığını saptamakiçin 6-25 yıl arasında değişen mesleki deneyime sahip 8 fen ve teknoloji öğretmeni ile alanı fen ve fizik eğitimi olan 3 öğretim üyesinden; dilbilgisi ve anlaşılırlık yönünden de bir dil uzmanından görüş alınmıştır. Veri toplama aracında yer alan ifadelerin anlaşılırlığı ile görünüş geçerliliğinin uygun olup olmadığını ve cevaplama süresini belirlemek amaciyla altınc1 sınıfta öğrenim görmekte olan 42 öğrenci ile pilot uygulama yapılmıştır. Uzman görüşleri ve pilot uygulama sonucunda veri toplama aracının nihai hali oluşturulmuştur. Veri toplama aracındaki ilk soruda 5. sınıf öğrencilerinden kendilerine verilen 4 devre içinden pil sayısının lamba parlaklığı üzerindeki etkisini karşılaştırmalı olarak inceleyebilecekleri 2 devre seçmeleri ve yaptıkları seçime ilişkin gerekçelerini ifade etmeleri istenmiştir. Veri toplama aracındaki ikinci soruda ise 5. sınıf öğrencilerinden kendilerine verilen 4 devre içinden lamba sayısının lamba parlaklığı üzerindeki etkisini karşılaştırmalı olarak inceleyebilecekleri 2 devre seçmeleri ve yaptıkları seçime ilişkin gerekçelerini ifade etmeleri istenmiştir.

\section{Verilerin Analizi}

Araştırmanın verileri içerik analizi ile çözümlenmiştir. Veri toplama aracının ön ve son test olarak uygulanması sonucunda toplanan cevap kâğıtlarına her öğrenci için bir numara verilmiştir. Cevaplar veri kâğıtlarına verilen numaralarla birlikte her soru için tek tek yazılmıştır. Araştırmanın kavramsal çerçevesinde ve araştırma sorularında yer alan boyutlar temel alınarak araştırma öncesinde hazırlanan çerçeveye uygun olacak biçimde verilerin yerleştirileceği temalar belirlenmiştir. Daha önceden belirlenen çerçeveye göre veriler okunmuştur. Önceden belirlenen çerçeveye uygulama sonunda saptanan yeni kod ve kategoriler de eklenmiştir. Veriler anlamlı ve mantıklı olacak şekilde birleştirilmiş, tanımlanmış, açıklanmış, ilişkilendirilmiş ve anlamlandırılmıştır.

İçerik analizi sürecinde veriler kodlanmış, temalar oluşturulmuş, veriler kodlara ve temalara göre düzenlenmiş ve tanımlanmış, bulgular yorumlanmıştır (Yıldırım \& Şimşek, 2011). Kategorilere yerleştirilen cevapların frekans ve yüzde değerleri hesaplanmıştır. Ortak kategorileri oluşturabilmek amacıyla öğrencilerin verdileri cevaplar karşılaştırılmıştır. Ortak kategoriler ile bu kategorilerin frekans ve yüzde değerleri kullanılarak tablolar hazırlanmış, hazırlanan tablolar yorumlanmıştır. Öğrencilerin ifadelerini açık ve net bir biçimde yansıtabilmek için oluşturulan alt ve ana temalara yerleştirilen veriler öğrencilerin ifadelerinden doğrudan alıntılarla desteklenmiştir. 


\section{Bulgular}

Öğrencilerin verdikleri cevaplar analiz edilerek frekans ve yüzde değerleri ile birlikte Tablo 4 ve Tablo 5'te sunulmuştur.

Pil sayısının lamba parlaklığı üzerindeki etkisinin araştırıldığı bir deney için kullanılabilecek devre çifti için frekans ve yüzde değerleri Tablo 4'te verilmiştir.

Görkem basit bir elektrik devresinde pil sayısının lamba parlaklığına etkisini araştırmak istiyor. Buna göre Görkem araştırmasında aşağıda verilen devrelerden hangi ikisini kullanmalıdır? Cevabınızın nedenini açıklayınız.

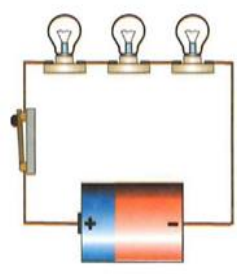

1.devre

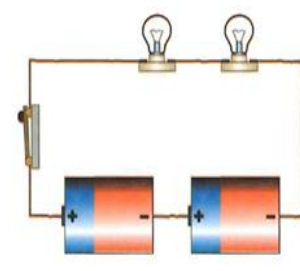

2.devre

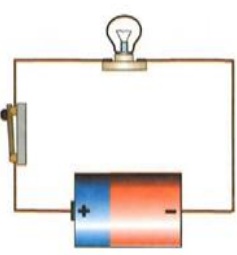

3.devre

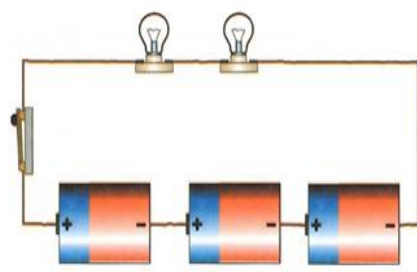

4.devre

Tablo 4

Pil Sayısının Lamba Parlaklığına Etkisini Araştırmak için Kullanılacak Devre Çiftine İlişkin Gerekçeli Cevapların Frekans ve Yüzde Değerleri

\begin{tabular}{|c|c|c|c|c|c|c|c|c|c|c|}
\hline \multirow{3}{*}{ Devre } & \multirow{3}{*}{\multicolumn{2}{|c|}{ Gerekçe }} & \multicolumn{4}{|c|}{ ÖN TEST } & \multicolumn{4}{|c|}{ SON TEST } \\
\hline & & & \multicolumn{2}{|c|}{ DG } & \multicolumn{2}{|c|}{ KG } & \multicolumn{2}{|c|}{ DG } & \multicolumn{2}{|c|}{ KG } \\
\hline & & & $\mathrm{f}$ & $\%$ & $\mathrm{f}$ & $\%$ & $\mathrm{f}$ & $\%$ & $\mathrm{f}$ & $\%$ \\
\hline \multirow{5}{*}{$2-4^{*}$} & \multicolumn{2}{|c|}{ Lamba sayısı aynı, pil sayısı farklı* } & 6 & 12.2 & 2 & 4.1 & 23 & 46.9 & 12 & 24.5 \\
\hline & \multicolumn{2}{|c|}{ Pil sayıs1, elektrik enerjisi fazla } & 9 & 18.4 & 5 & 10.2 & 5 & 10.2 & 6 & 12.2 \\
\hline & \multicolumn{2}{|c|}{ En parlak devre çifti } & - & - & 2 & 4.1 & 2 & 4.1 & 3 & 6.1 \\
\hline & \multicolumn{2}{|c|}{ Gerekçe yok } & 2 & 4.1 & 4 & 8.2 & 5 & 10.2 & - & - \\
\hline & \multicolumn{2}{|l|}{ Toplam } & 17 & 34.7 & 13 & 26.5 & 35 & 71.4 & 21 & 42.9 \\
\hline \multirow{3}{*}{$1-2$} & \multicolumn{2}{|c|}{ En parlak devre çifti } & - & - & 1 & 2.0 & - & - & - & - \\
\hline & \multicolumn{2}{|c|}{ Gerekçe yok } & - & - & 3 & 6.1 & 2 & 4.1 & 3 & 6.1 \\
\hline & \multicolumn{2}{|l|}{ Toplam } & - & - & 4 & 8.2 & 2 & 4.1 & 3 & 6.1 \\
\hline \multirow{8}{*}{$1-3$} & \multicolumn{2}{|c|}{ Pil sayısı aynı, lamba sayısı farklı } & - & - & 2 & 4.1 & - & - & 1 & 2.0 \\
\hline & \multirow[t]{2}{*}{ Pil } & Say1s1 az & - & - & - & - & - & - & 1 & 2.0 \\
\hline & & $\begin{array}{l}\text { Lambalara vereceği 1şıkta } \\
\text { artış }\end{array}$ & 2 & 4.1 & - & - & - & - & - & - \\
\hline & \multirow[t]{2}{*}{ Lamba } & Sayısı farklı & - & - & - & - & 1 & 2.0 & - & - \\
\hline & & $\begin{array}{l}\text { Iş1k verme süresinde } \\
\text { azalma }\end{array}$ & - & - & 1 & 2.0 & - & - & - & - \\
\hline & \multicolumn{2}{|c|}{ Parlaklıkta azalma } & 1 & 2.0 & 2 & 4.1 & - & - & 1 & 2.0 \\
\hline & \multicolumn{2}{|c|}{ Gerekçe yok } & - & - & 1 & 2.0 & - & - & 1 & 2.0 \\
\hline & \multicolumn{2}{|l|}{ Toplam } & 3 & 6.1 & 6 & 12.2 & 1 & 2.0 & 4 & 8.2 \\
\hline
\end{tabular}




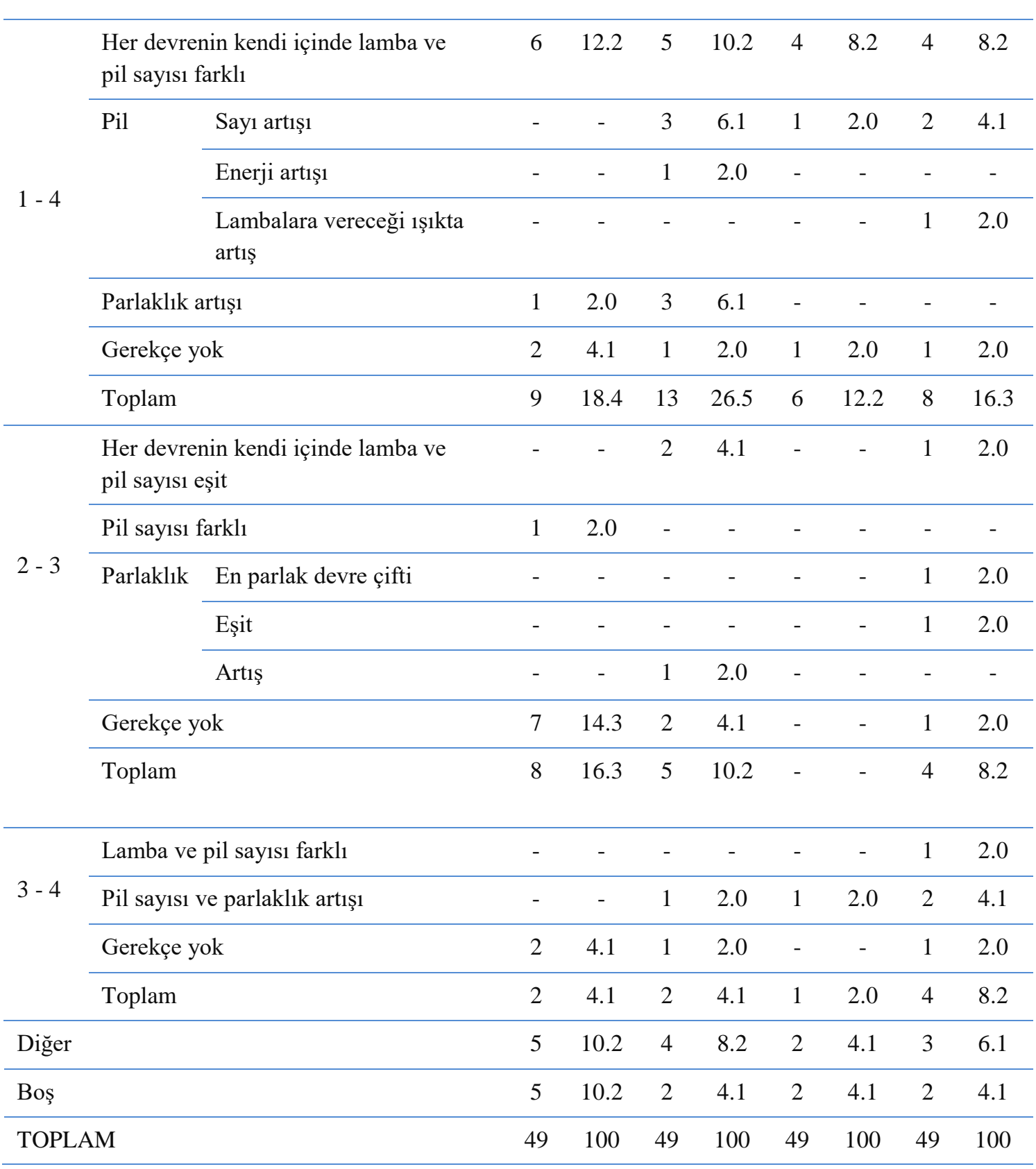

*: Doğru cevap

Tablo incelendiğinde ön testte deney grubundaki öğrencilerin \%34.7'si, kontrol grubundaki öğrencilerin ise $\% 26.5$ 'i; son testte ise deney grubundaki öğrencilerin \%71.4'ü, kontrol grubundaki öğrencilerin ise \%42.9'u 2 ve 4 nolu devre çiftini seçerek doğru cevap vermiştir. Soruya doğru cevap veren öğrencilerden ön testte deney grubundaki öğrencilerin \%12.2'si, kontrol grubundaki öğrencilerin \%4.1'i; son testte ise deney grubundaki öğrencilerin \%46.9'u, kontrol grubundaki öğrencilerin \%24.5'i 2 ve 4 nolu devre çiftini seçme nedenlerini doğru bir gerekçe ile desteklemiştir.

2 ve 4 nolu devreleri seçen öğrencilerin cevaplarında ifade ettikleri gerekçelerden bazı örnekler aşağıda sunulmuştur.

Öğrencilerin bu devre çiftini seçme nedenleri incelendiğinde lamba ve pil sayısı kategorisinde ön testte deney grubunda 6 öğrenci (\%12.2) "Lamba sayları aynı, pil sayıları farklı olduğu için”, kontrol grubunda 2 öğrenci (\%4.1) "Lamba sayıları aynı, pil sayıları farklı olduğu için"; son testte deney grubunda 23 öğrenci (\%46.9) "Pil sayısı değişken, lamba sayısı aynı olduğu için”, "Lamba sayıları sabit kalıp, pil sayıları 
değiştiği için", kontrol grubunda ise 12 öğrenci (\%24.5) "Lamba sayıları aynı, pil sayıları farklı olduğu için", "Lamba sayısı sabit olup, pil sayısı değiştiği için" gerekçeleri ile 2 ve 4 nolu devre çiftini seçmiştir. Bu gerekçelerden öğrencilerin pil sayısının lamba parlaklığına etkisinin araştırıldığı bir deney için pil sayısının değiştirildiği, lamba sayısının ise kontrol altında tutulduğu durumun lamba parlaklığ üzerindeki etkisinin incelenmesinde pil sayısının bağımsız değişken, lamba sayısının ise kontrol edilen değişken olduğunu dikkate aldıkları anlaşılmıştır. Öğrencilerin herhangi bir durum üzerinde nasıl bir etki oluşturacağını görmek istedikleri değişkeni değiştirirken durumu etkilemesi muhtemel olan diğer değişkeni kontrol altında tuttukları görülmüştür.

Pil sayısı ve elektrik enerjisi kategorisinde ön testte deney grubunda 9 öğrenci "Pil sayısı fazla olduğu için", "İki devrede de l'den fazla pil olduğu için”, "Parlaklı̆̆ın artması için pil sayısı fazla olması gerektiği için", kontrol grubunda 5 öğrenci "Daha çok pil olduğu için”, "Pil sayısı fazla olduğu için”; son testte deney grubunda 5 öğrenci "Pil sayısının çok olması lamba parlaklı̆̆ını nasıl etkiler anlamak için", "Pil sayısı arttı̆̆ için", kontrol grubunda ise 6 öğrenci "Pil sayısı çok fazla olduğu için”, "Pil daha çok enerji vereceği için”, "Pil sayısı arttı̆̆ için” gerekçeleri ile 2 ve 4 nolu devre çiftini seçmişlerdir. Bu gerekçeler öğrencilerin lamba parlaklığının sadece pil sayısındaki değişimden etkilendiğini, lamba sayısının parlaklık üzerinde etkisi olmadığını düşündüklerini ortaya koymaktadır. Öyle ki, görüşmelerde de bazı öğrencilerin "Lamba sayısının değiştirilmesinin parlaklık üzerinde etkisi olmaz." ifadeleri bu bulguyu destekler niteliktedir. Öğrencilerin bir devrede pil olmazsa lamba zaten 1 şık veremez. Lambanın 1şık vermesi devredeki pile bağlıdır. Pil ne kadar çok olursa 1şık da o kadar çok olur yaklaşımı ile 2 ve 4 nolu devre çiftlerini seçmiş olabilecekleri düşünülmektedir. Saptanan bu yanılg1 "Parlaklık Üzerindeki Tek Etki: Pil Sayısı Modeli" olarak adlandırılmıştır. Ayrıca bu öğrencilerde lamba sayısındaki değişimin parlaklık üzerinde herhangi bir etkisi olmayacağını düşünmeleri nedeni ile "Lamba Başına Düşen Enerji Modeli" kavram yanılgısı da söz konusudur. Bu öğrencilerin devreye eklenen her lambanın pilin enerjisine ortak olacağını ve pilin enerjisinin devredeki lambalar arasında paylaşılacağını bilmedikleri düşünülmektedir.

Parlaklık kategorisinde ön testte kontrol grubunda 2 öğrenci "Daha parlak oldukları için"; son testte ise deney grubunda 2 öğrenci "2. 'de lamba sayısı pil sayısına eşit olup parlaklıklar eşit olup, 4.'de lamba sayısı pil sayısından az olup parlaklık arttığ devrelerden daha parlak oldukları için” gerekçeleri ile 2 ve 4 nolu devre çiftini seçmişlerdir. Öğrenciler pil sayısının fazla olması nedeni ile 2 ve 4 nolu devre çiftinin parlaklığının diğer devrelerden daha fazla olduğunu belirtmişlerdir. Öğrencilerin ifadelerinin aksine en parlak devreler 2 ve 4 nolu devreler değildir. Soruda verilen devrelerin parlaklıkları arasında $4>2=3>1$ siralaması söz konusudur. Bu durumda 2 ve 3 nolu devreler eşit parlaklıkta olduğu için 2 ve 4 nolu devrelerin parlaklığının diğer devrelerden fazla olduğu düşüncesi kavram yanılgısı içermektedir. $\mathrm{Bu}$ durum öğrencilerin pilin enerjisinin lambalar arasındaki paylaşımını ve lamba başına düşecek enerji miktarını göz ardı ederek sadece görsel olarak pil sayısının fazla olma durumunda parlaklığın da fazla olacağı şeklinde önemli bir kavram yanılgısına sahip olduklarını ortaya koymaktadır. Öğrencilerde tespit edilen kavram yanılgısı "Lamba Başına Düşen Enerji Modeli” olarak ifade edilmiştir. Böyle bir düşünce 2. devrenin 3. devreden daha 
parlak olduğunu iddia eden öğrencilerin lamba sayısına dikkat etmeksizin pil sayısının fazla olduğu her durumda lambanın daha parlak yanacağına inandıklarını ortaya koymaktadır. Ayrıca bu öğrencilerde "Parlaklık Üzerindeki Tek Etki: Pil Sayısı Modeli" kavram yanılgısı da söz konusudur.

1 ve 2 nolu devreleri seçen öğrencilerin cevaplarında ifade ettikleri gerekçelerden bazı örnekler aşağıda sunulmuştur.

Ön testte kontrol grubunda 4 öğrenci; son testte ise deney grubunda 2 öğrenci, kontrol grubunda 3 öğrenci 1 ve 2 nolu devre çiftini seçmiştir.

Kontrol grubundaki 1 öğrenci parlaklık kategorisinde "3 ve 4 devrelerinden daha parlaklar. 3 lamba 2 lambadan daha aydınlık olduğu için, onlarda parlaklık daha fazla olur." gerekçesi ile 1 ve 2 nolu devre çiftini seçmiştir. Devrelerin parlaklık sıralaması $4>2=3>1$ şeklinde olduğu için 1 ve 2 nolu devrelerin diğer devrelerden daha parlak olma durumu söz konusu değildir. Buradan öğrencinin görsel olarak lamba sayıları üzerinde yoğunlaştığı, lamba sayısının çok olduğu bir devrede 1şı̆̆ın daha çok olacağını düşündüğü anlaşılmaktadır. Öğrencide alanyazından farklı olarak 3 lambanın toplam ışı̆̆ 1 (devre 1) ile 2 lambanın toplam 1şı̆̆ının (devre 2) 3 ve 4 nolu devrelerden daha fazla olacağına ilişkin kavram yanılgılı bir düşünce hâkimdir. Öğrenci 3 lambanın bir ortamı 2 lambadan daha fazla aydınlatacağına inanmaktadır. Bu yanılgıya sahip öğrenci devrenin enerji kaynağını ve lambalar arasındaki enerji paylaşımını göz ardı etmektedir. 1 ve 2 nolu devreleri seçen öğrenci devredeki lambaların ayrı ayrı yaydığı 1şığı tek bir kaynaktan çıkıyormuş gibi düşünmektedir. Alanyazından farklı olarak araştırmada saptanan kavram yanılgısı "Devredeki Lambaların Yaydığı Toplam Işık Modeli” olarak adlandırılmıştır. Ayrıca bu öğrencide "Lamba Başına Düşen Enerji Modeli" ve "Parlaklık Üzerindeki Tek Etki: Lamba Sayısı Modeli" kavram yanılgıları da söz konusudur.

1 ve 3 nolu devreleri seçen öğrencilerin cevaplarında ifade ettikleri gerekçelerden bazı örnekler aşağıda sunulmuştur.

Ön testte deney grubunda 3 öğrenci, kontrol grubunda 6 öğrenci; son testte deney grubunda 1 öğrenci, kontrol grubunda ise 4 öğrenci 1 ve 3 nolu devre çiftini seçmiştir.

Ön testte kontrol grubunda 2 öğrenci, son testte ise 1 öğrenci 1 ve 3 nolu devre çiftini seçmiştir. Öğrenciler pil ve lamba sayısı kategorisinde ön testte "Pil sayısı aynı, lamba saylsi farklı", son testte ise "1'de 1 pil 3 lamba, 3'de 1 pil 3 lamba var. Pil sayıları aynı lamba sayıları farklı olduğu için” gerekçeleri ile cevaplarını desteklemişlerdir. Bu durum öğrencilerin bağımsız ve kontrol edilen değişken türlerini birbirine karıştırdıklarını; ayrıca hangi değişkeni sabit tutup hangisini değiştirecekleri konusunda kavram yanılgısına sahip olduklarını ortaya koymaktadır. Öğrencilerin ifade ettiği gibi pil sayısının sabit tutulup lamba sayısının değiştirilmesi durumunda pil sayısı yerine lamba sayısının lamba parlaklığı üzerindeki etkisi görülür. Öğrencilerde pil sayısının lamba parlaklığı üzerindeki etkisinin pil sayısı sabit tutulup lamba sayısının değiştirildiği durumda gözlenebileceğine dair kavram yanılgısı içeren bir düşünce hâkimdir.

Son testte kontrol grubundaki 1 öğrenci pil sayısı kategorisinde "Pil saylsı az olan devreler oldukları için" 1 ve 3 nolu devre çiftini seçmiştir. Öğrencinin lamba parlaklığı üzerinde lamba sayısının herhangi bir etkisi olmadığını düşündüğü ve devre 
çiftini seçerken pil sayılarına göre karar verdiği anlaşılmıştır. Öğrencide "Parlaklık Üzerindeki Tek Etki: Pil Sayısı Modeli” yanılgısı mevcuttur.

Ön testte deney grubunda 2 öğrenci pilin lambalara vereceği sşık kategorisinde "1 pil 3 lambaya az ışık verirken 1 pil 1 lambaya daha fazla ışık vereceği için" gerekçesi ile 1 ve 3 nolu devreleri seçmiştir. Öğrencilerde pilin lambalara vereceği 1şıkta artış olacağı düşüncesi hâkimdir. Bu bulgu öğrencilerde plin devredeki rolüne ilişkin kavram yanılgısı olduğunu ortaya koymaktadır. Ayrıca bu öğrencilerde devrede gerçekleşen enerji dönüşümü ile ilgili olarak da yanılgı olduğu düşünülmektedir. Öyle ki pil devrenin elektrik enerjisi kaynağıdır ve pilin devreye sağladığı elektrik enerjisi lambada 1sı ve 1ş1k enerjisine dönüşmektedir. Basit bir elektrik devresinde elektrik enerjisi kaynă̆ı pil, 1şık kaynağı ise lambadır. Pili lambalara 1şık veren bir kaynak olarak düşünen ve pilin lambalara vereceği 1şığın artacağını ifade eden öğrencilerin az sayıda pil içeren devreleri seçmeleri dikkat çekicidir. Öğrencilerin pil sayısının lamba parlaklığı üzerindeki etkisini tam olarak bilmedikleri ve pil sayısı azken pilin lambalara daha fazla 1 şı vereceğine inandıkları düşünülmektedir. Öğrencilerde saptanan yanılgılar "Işık Kaynağı Olarak Pil Modeli", "Enerji Dönüşümü Modeli” ve "Pil SayısıParlaklık İlişkisi Modeli” olarak adlandırılmıştır.

Son testte deney grubundaki 1 öğrenci lamba sayısı kategorisinde "Lamba sayısı farklı" gerekçesi ile 1 ve 3 nolu devre çiftini seçmiştir. Pil sayısının lamba parlaklığ üzerindeki etkisini görmek için lamba sayısının sabit tutulması, pil sayısının değiştirilmesi gerekir. Öğrencinin değişken türlerini farklı bir duruma transfer etmede güçlük yaşadığı anlaşılmıştır. Öğrencide pil sayılarına dikkat etmeden sadece lamba sayılarına dikkat ederek lamba sayısının değiştirildiği durumda parlaklığın gözlenebileceğine dair yanılgılı bir düşünce hâkimdir. Bu öğrenci lamba parlaklığı üzerinde etkili olan tek değişkeni lamba sayısı olarak kabul etmektedir. Alanyazından farklı olarak araştırmada saptanan bu yanılgı "Parlaklık Üzerindeki Tek Etki: Lamba Sayısı Modeli” olarak adlandırılmıştır.

Ön testte kontrol grubundaki 1 öğrenci lamba sayısına bağlı 1şık verme süresi kategorisinde "3 daha fazla dayanırken 1 fazla dayanamayacağı için lambanın ışık vereceği süre azalır." gerekçesi ile 1 ve 3 nolu devre çiftini seçmiştir. Alanyazından farklı bir yanılgı da lamba sayısı ile lambanın 1şık verme süresi arasında bir ilişki olduğuna yöneliktir. Yapılan görüşmelerde öğrenci cevabını "Lamba sayısı arttıkça lambanın yanma süresi artar. Önce ilk lamba yanar, söner. Sonra ikinci lamba yanmaya başlar ve süre uzun olur." ifadesi ile gerekçelendirmiştir. Öğrenci devreye seri bağlanan lambaların aynı anda 1şık vermeyeceğini, lambalardan önce birinin yanacağını, bu lambanın tamamen tükenince söneceğini, ardından diğer lambanın yanmaya başlayacağını ve böylece devrenin daha uzun süre 1ş1k vereceğini düşünmektedir. Öğrencide saptanan bu yanılgı "Lamba Sayısına Bağlı Işık Verme Süresi Modeli" olarak adlandırılmıştır.

Ön testte deney grubunda 1 öğrenci, kontrol grubunda 2 öğrenci; son testte ise kontrol grubunda 1 öğrenci parlaklık kategorisinde "Lamba sayısı azalacă̆ için parlaklıkta azalma" gerekçesi ile 1 ve 3 nolu devre çiftini seçmiştir. Öğrenciler 1. devreden 3. devreye geçişte lamba parlaklığının azalacağını ifade etmiştir. Öğrencilerin ifade ettikleri gerekçenin aksine 1. devreden 3. devreye geçişte pil sayısı sabitken lamba sayısı azaldığı için parlaklık artacaktır. Bu bulguya göre öğrenciler devrede yer alan 1şık kaynaklarının ayrı ayrı yaydığı 1şığı tek bir 1şık kaynağından çıkıyormuş gibi 
düşünmektedir. Bu yanılgıya sahip öğrenciler için devrede ne kadar çok lamba olursa o devre o kadar parlak olur düşüncesi hâkimdir. Bu yanılgı alanyazından farklı olarak bu araştırmada saptanmış olup "Devredeki Lambaların Yaydığı Toplam Işık Modeli" olarak adlandırılmıştır.

1 ve 4 nolu devreleri seçen öğrencilerin cevaplarında ifade ettikleri gerekçelerden bazı örnekler aşağıda sunulmuştur.

Lamba ve pil sayısı kategorisinde ön testte deney grubunda 6 öğrenci "Diğer devrelerde lamba ve pil saylları eşit olduğu için", "Diğer devrelerdeki pil ve lamba sayıları aynı olduğu için”, "İki devrede de pil ve lamba sayıları farklı olduğu için”, kontrol grubunda 5 öğrenci "1.de 3 lamba 1 pil, 4.de 2 lamba 3 pil olduğu için 1 ve 4 'de lamba ve pil sayıları farklı"; son testte deney ve kontrol grubunda 4 öğrenci "Pil ve lamba sayıları eşit olmadiğı için”, "Birinde pil çok lamba az, diğerinde ise pil az lamba çok olduğu için" gerekçeleri ile 1 ve 4 nolu devre çiftini seçmiştir. Bu durum öğrencilerin değişken türlerini belirleme ve kontrol etmede güçlük yaşadıklarını ortaya koymaktadır. Pil sayısının lamba parlaklığı üzerindeki etkisinin araştırıldığ 1 deneyde lamba parlaklığı üzerinde etkili olan değişkenler olarak lamba sayısının ve pil sayısının her ikisinin de değiştiği durumda lamba parlaklığı üzerinde pil sayısındaki değişimin oluşturacağı etkinin gözlemlenmesi mümkün değildir. Bağımlı değişken üzerinde etkili olan değişkenler dikkate alınarak hangi değişkenin etkisi araştırılacaksa o değişken değiştirilirken diğer değişken kontrol altında tutulmalıdır. Ancak bu şekilde sonucu etkileyen birden fazla değişkenin ayrı ayrı etkileri hakkında yorum yapılabilir. Öğrencilerde saptanan kavram yanılgısı "Değişkeni Belirleme ve Kontrol Etme Modeli" olarak adlandırılmıştır. Bu yanılgıya sahip öğrenci hem etkisi incelenecek değişkeni hem de kontrol altında tutulması gereken değişkeni aynı anda değiştirmektedir.

Pil sayısı ve enerji kategorisinde ön testte kontrol grubunda 3 öğrenci " 4 . de pil çok 1. de pil az olduğu için", "Pil sayısı artınca parlaklık artacă̆ için”, "I'de pil az lamba çok, 4'de lamba az pil çok olduğu için”; son testte deney grubunda 1 öğrenci "1 nolu devrede pil sayısı az, 4 nolu devrede ise pil sayısı en çoktur.", kontrol grubunda 2 öğrenci "Pil sayısındaki artış", "1. devreden 4. devreye geçişte pil sayısı artmıştır." gerekçeleri ile 1 ve 4 nolu devre çiftini seçmiştir. Ayrıca ön testte kontrol grubundaki 1 öğrenci "3 pil daha fazla enerji verirken 1 pil daha az enerji vereceği için", "Pil sayısındaki artışla enerji artışı" gerekçesi ile 1 ve 4 nolu devre çiftini seçmiştir. Bu durumdan öğrencilerin lamba parlaklığı üzerinde sadece pil sayısının etkili olduğunu düşündükleri anlaşılmaktadır. Öğrenciler devrelerdeki lamba sayısına bakmadan pil sayısı üzerinde yoğunlaşarak az ve çok pil sayısına sahip olan devreleri seçmiştir. Öğrencilerin pil sayısının lamba parlaklığı üzerindeki etkisini araştırırken pil sayısının arttığı, azaldığı ya da birbirinden farklı olduğu devreleri seçerek lamba sayısını dikkate almayacakları düşünülmektedir. $\mathrm{Bu}$ durum öğrencilerde lamba parlaklığı üzerinde sadece pil sayısının etkili olduğu şeklinde bir yanılgı olduğunu ortaya koymaktadır. Bu öğrencilerde "Parlaklık Üzerindeki Tek Etki: Pil Sayısı Modeli” ile "Lamba Başına Düşen Enerji Modeli” yanılgıları söz konusudur.

Son testte kontrol grubundaki 1 öğrenci ise pilin lambalara vereceği $1 s ̧ 1 \mathrm{k}$ kategorisinde "1. de 1 pil 3 lambaya ışık verdiği için her birine az ışık düşer. 4. de 3 pil 2 lambaya ışık verir. Her bir lambaya çok ışık düşer." gerekçesi ve pil sayısı artınca pilin lambalara vereceği 1şık artar düşüncesi ile 1 ve 4 nolu devre çiftini seçmiştir. Bu öğrencinin devrenin elektrik enerjisi kaynağı olan pili lambalara 1şık veren bir kaynak 
olarak gördügü anlaşılmıştır. Öğrencide pilin devredeki rolü ve devrede gerçekleşen enerji dönüşümü ile ilgili kavram yanılgısı mevuttur. Öyle ki pil devreye elektrik enerjisi sağlar. $\mathrm{Bu}$ elektrik enerjisi lambada $1 \mathrm{~s} 1$ ve 1 şı enerjisine dönüştürülür. Öğrencide "Işık Kaynağı Olarak Pil Modeli” ve "Enerji Dönüşümü Modeli” yanılgıları saptanmıştır.

Parlaklık kategorisinde ön testte deney grubunda 1 öğrenci "Parlaklık artışı", kontrol grubunda 3 öğrenci "1. devreden 4. devreye çevirince parlaklık artar.”, "4. de ışılk fazla 1. de ışılk az olduğu için” gerekçeleri ile 1 ve 4 nolu devre çiftini seçmiştir. 1. devreden 4. devreye geçişte lamba sayısı azalırken pil sayısı arttığı için lamba parlaklığı artar. Ancak değişken türlerini belirleme ve kontrol etme kazanımlarının amaçlandığ 1 düşünülürse bu devreler pil sayısının lamba parlaklığı üzerindeki etkilerini incelemek için uygun değildir. Bununla birlikte bilimsel süreç becerilerinin önemli bir basamağını oluşturan değişkenleri belirleme ve kontrol etme becerisinin kullanılacağı durumlarda iki değişkende aynı anda değişim gösteremez. Sonuç üzerinde etkisi araştırılan değişken değiştirilirken sonucu etkileyebilecek diğer değişkenler kontrol altında tutulmalıdır. Öğrencilerin ifade ettikleri gerekçeler değişkenleri belirleme ve kontrol etme olarak adlandırılan bilimsel süreç becerisinin doğasına aykırıdır.

2 ve 3 nolu devreleri seçen öğrencilerin cevaplarında ifade ettikleri gerekçelerden bazı örnekler aşağıda sunulmuştur.

Lamba ve pil sayısı kategorisinde ön testte kontrol grubunda 2 öğrenci "Lamba ve pil sayısı eşit olduğu için", "Eşit sayıda pil ve lamba olduğu için"; son testte ise 1 öğrenci "2. devrede lamba sayısı pil sayısına eşit, 3. devrede lamba sayısı pil sayısına eşittir. 2 pil 2 lamba, 1 pil 1 lamba ile karşılaştırılabileceği için” gerekçeleri ile 2 ve 3 nolu devre çiftini seçmiştir. Öğrencilerin yaptıkları devre seçiminde 2 ve 3 nolu devrelerin parlaklıkları eşit olduğu için pil sayısının lamba parlaklığı üzerindeki etkilerini gözlemlemek mümkün değildir.

Ön testte deney grubundaki 1 öğrenci pil sayısı kategorisinde "Pil lambanın enerjisini arttırır. Pil sayısının parlaklı̆̆a etkisi daha çok olur. 2'de 2 pil, 3'de 3 pil olduğu için" gerekçesi ile pil sayıları farklı olduğu için 2 ve 3 nolu devre çiftini seçmiştir. 2 ve 3 nolu devrelerde lamba sayısı da farklıdır. Bu bulgudan öğrencinin lamba sayısının lamba parlaklığı üzerinde etkili olmadığını düşündüğü anlaşılmaktadır. Seçilecek devrelerde pil sayılarının farklı, lamba sayılarının da aynı olması gerekmektedir. $\mathrm{Bu}$ öğrencide saptanan yanılgı "Parlaklık Üzerindeki Tek Etki: Pil Sayısı Modeli” olarak adlandırılmıştır.

Son testte kontrol grubundaki 1 öğrenci parlaklık kategorisinde "2 devrede diğerlerinden çok parlak olacă̆ için” gerekçesi ile 2 ve 3 nolu devre çiftini seçmiştir. 4>2=3>1 parlaklık sıralaması dikkate alındığında 4 nolu devrenin en parlak devre olduğu görülmektedir. Bu durum öğrencilerin pil ve lamba sayısına bağlı lamba parlaklığındaki değişimi anlamada zorlandıklarını ortaya koymaktadır.

Son testte kontrol grubundaki 1 öğrenci parlaklık kategorisinde "Parlaklıkları aynı olacă̆ı için" gerekçesi ile 2 ve 3 nolu devreleri seçmiştir. Parlaklıkları eşit olan iki devrede pil sayısının lamba parlaklığı üzerindeki etkisini gözlemlemek mümkün değildir.

Ön testte kontrol grubundaki 1 öğrenci ise parlaklık kategorisinde "3. devrede 1 pil var. 1 milim parlaklık, 2. devrede 2 pil var. 2 milim parlaklık olacă̆ı için 3. 
devreden 2. devreye geçişte parlaklık artışı olur." gerekçesi ile 2 ve 3 nolu devre çiftini tercih etmiştir. Bu tercih öğrencinin lamba parlaklığı üzerinde lamba sayısının ve lamba başına düşen enerji miktarındaki değişimin herhangi bir etkisi olmadığını düşündügünü ve sadece pil sayılarına bakarak karar verdiğini ortaya koymaktadır. Bu düşünce öğrencinin 2 ve 3 nolu devrelerin eşit parlaklıkta olduğunu fark etmesini engellemektedir. Öğrencide saptanan bu yanılgılar "Parlaklık Üzerindeki Tek Etki: Pil Sayısı Modeli” ve "Lamba Başına Düşen Enerji Modeli” olarak adlandırılmıştır.

3 ve 4 nolu devreleri seçen öğrencilerin cevaplarında ifade ettikleri gerekçelerden bazı örnekler aşağıda sunulmuştur.

Son testte kontrol grubunda 1 öğrenci lamba ve pil sayısı kategorisinde " 3 'de 1 pil 1 lamba, 4'de 2 lamba 3 pil olduğu için lamba ve pil sayısı farklıdır." gerekçesi ile 3 ve 4 nolu devre çiftini seçmiştir. Bu durum öğrencinin değişkenleri belirleme ve kontrol etme konusunda güçlük yaşadığını ortaya koymaktadır. Lamba sayısı ve pil sayısının lamba parlaklığı üzerinde etkili olma durumu dikkate alındığında iki değişkenin de aynı anda değiştirildiği durumlar için lamba parlaklığının hangi değişkenden etkilendiğini belirlemek mümkün değildir.

Pil sayısı ve parlaklık kategorisinde ön testte kontrol grubunda 1 öğrenci “3. devrede pil ve lamba saylsı az, 4. devrede pil ve lamba sayısı çok"; son testte deney grubunda 1 öğrenci, kontrol grubunda ise 2 öğrenci "Pil sayısı 4. devrede fazla olduğu için 3. devreden 4. devreye geçişte parlaklık artar." gerekçesi ile 3 ve 4 nolu devre çiftini seçmiştir. Öğrenciler lamba sayılarına ve lamba başına düşen enerji miktarına dikkat etmeden sadece pil sayılarına bakarak parlaklık hakkında yorum yapmıştır. Öğrencilerde "Lamba Başına Düşen Enerji Modeli” ve "Parlaklık Üzerindeki Tek Etki: Pil Sayısı Modeli” kavram yanılgıları saptanmıştır.

Lamba sayısının lamba parlaklığı üzerindeki etkisinin araştırıldığı bir deney için kullanılabilecek devre çifti için frekans ve yüzde değerleri Tablo 5 'te verilmiştir.

Görkem basit bir elektrik devresinde lamba sayısının lamba parlaklığına etkisini araştırmak istiyor. Buna göre Görkem araştırmasında aşağıda verilen devrelerden hangi ikisini kullanmalıdır? Cevabınızın nedenini açıklayınız.

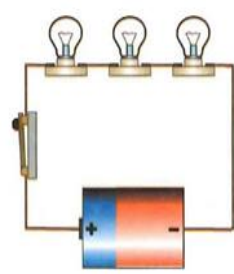

1.devre

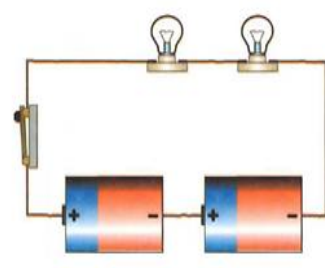

2.devre

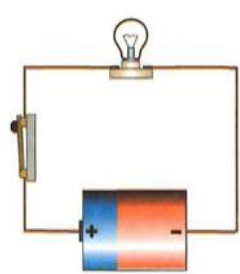

3.devre

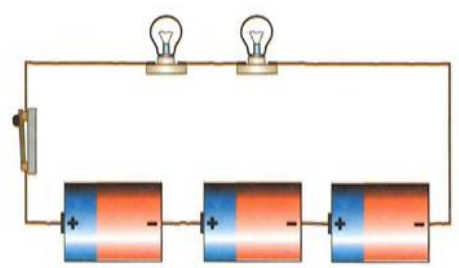

4.devre

Tablo 5

Lamba Sayısının Lamba Parlaklı̆̆ına Etkisini Araştırmak için Kullanılacak Devre Çiftine İlişkin Gerekçeli Cevapların Frekans ve Yüzde Değerleri

\begin{tabular}{ccccccccccc}
\hline \multirow{2}{*}{ Devre Gerekçe } & \multicolumn{4}{c}{ ÖN TEST } & \multicolumn{4}{c}{ SON TEST } \\
\cline { 2 - 9 } & \multicolumn{2}{c}{ DG } & \multicolumn{2}{c}{ KG } & \multicolumn{2}{c}{ DG } & & \multicolumn{2}{c}{ KG } \\
\cline { 2 - 9 } & & f & $\%$ & f & $\%$ & f & $\%$ & f & $\%$ \\
\hline Pil sayısı aynı, lamba sayısı farklı* & 5 & 10.2 & 4 & 8.2 & 27 & 55.1 & 10 & 20.4 \\
\hline
\end{tabular}




\begin{tabular}{|c|c|c|c|c|c|c|c|c|c|c|}
\hline \multirow{4}{*}{$1-3^{*}$} & \multicolumn{2}{|c|}{ Lamba sayısında azalma } & - & - & 3 & 6.1 & 1 & 2.0 & 3 & 6.1 \\
\hline & \multicolumn{2}{|c|}{ Pil sayısı ve enerji az } & 1 & 2.0 & 1 & 2.0 & - & - & 1 & 2.0 \\
\hline & \multicolumn{2}{|c|}{ Gerekçe yok } & 1 & 2.0 & 4 & 8.2 & 2 & 4.1 & 5 & 10.2 \\
\hline & \multicolumn{2}{|c|}{ Toplam } & 7 & 14.3 & 12 & 24.5 & 30 & 61.2 & 19 & 38.8 \\
\hline \multirow{5}{*}{$1-2$} & \multicolumn{2}{|c|}{ Lamba sayıları farklı } & - & - & 2 & 4.1 & 2 & 4.1 & - & - \\
\hline & \multicolumn{2}{|c|}{ Pil sayısı ve enerji artışı } & 1 & 2.0 & 1 & 2.0 & - & - & - & - \\
\hline & \multicolumn{2}{|c|}{ En parlak devre çifti } & 1 & 2.0 & 1 & 2.0 & - & - & - & - \\
\hline & \multicolumn{2}{|c|}{ Gerekçe yok } & 1 & 2.0 & 2 & 4.1 & 1 & 2.0 & 1 & 2.0 \\
\hline & \multicolumn{2}{|c|}{ Toplam } & 3 & 6.1 & 6 & 12.2 & 3 & 6.1 & 1 & 2.0 \\
\hline \multirow{7}{*}{$1-4$} & \multicolumn{2}{|c|}{$\begin{array}{l}\text { Her devrenin kendi içinde lamba ve pil } \\
\text { sayısı farklı ve fazla }\end{array}$} & 5 & 10.2 & 8 & 16.3 & 3 & 6.1 & 3 & 6.1 \\
\hline & \multirow[t]{3}{*}{ Pil } & Sayısı farklı & - & - & 1 & 2.0 & - & - & - & - \\
\hline & & Vereceği 1ş1k artış1 & - & - & - & - & - & - & 1 & 2.0 \\
\hline & & Enerji artışı & 2 & 4.1 & 1 & 2.0 & - & - & - & - \\
\hline & \multicolumn{2}{|c|}{ Parlaklıkta artış } & 2 & 4.1 & 2 & 4.1 & - & - & - & - \\
\hline & \multicolumn{2}{|c|}{ Gerekçe yok } & 2 & 4.1 & - & - & 1 & 2.0 & 3 & 6.1 \\
\hline & \multicolumn{2}{|c|}{ Toplam } & 11 & 22.4 & 12 & 24.5 & 4 & 8.2 & 7 & 14.3 \\
\hline \multirow{4}{*}{$2-3$} & \multicolumn{2}{|c|}{$\begin{array}{l}\text { Her devrenin kendi içinde lamba ve pil } \\
\text { sayısı eşit }\end{array}$} & 2 & 4.1 & 3 & 6.1 & 1 & 2.0 & 1 & 2.0 \\
\hline & \multicolumn{2}{|c|}{ Parlaklıkları eşit } & - & - & 2 & 4.1 & - & - & - & - \\
\hline & \multicolumn{2}{|c|}{ Gerekçe yok } & 1 & 2.0 & - & - & - & - & 2 & 4.1 \\
\hline & \multicolumn{2}{|c|}{ Toplam } & 3 & 6.1 & 5 & 10.2 & 1 & 2.0 & 3 & 6.1 \\
\hline \multirow{5}{*}{$2-4$} & \multicolumn{2}{|c|}{$\begin{array}{l}\text { Lamba sayısı aynı, pil sayısı farklı } \\
\text { olduğu için }\end{array}$} & 2 & 4.1 & 2 & 4.1 & 4 & 8.2 & 5 & 10.2 \\
\hline & \multicolumn{2}{|c|}{ Pil sayısı fazla ve en parlak devre çifti } & 3 & 6.1 & 4 & 8.2 & 1 & 2.0 & 1 & 2.0 \\
\hline & \multicolumn{2}{|c|}{ Pilin lambalara vereceği 1şıkta artış } & 3 & 6.1 & - & - & - & - & - & - \\
\hline & \multicolumn{2}{|c|}{ Gerekçe yok } & 2 & 4.1 & 1 & 2.0 & 1 & 2.0 & 5 & 10.2 \\
\hline & \multicolumn{2}{|c|}{ Toplam } & 10 & 20.4 & 7 & 14.3 & 6 & 12.2 & 11 & 22.4 \\
\hline Hiçbiri & \multicolumn{2}{|c|}{ Lamba sayısı parlaklığı etkilemez } & 1 & 2.0 & - & - & - & - & - & - \\
\hline Diğer & & & 6 & 12.2 & 5 & 10.2 & 3 & 6.1 & 4 & 8.2 \\
\hline Boş & & & 8 & 16.3 & 2 & 4.1 & 2 & 4.1 & 4 & 8.2 \\
\hline TOPLA & & & 49 & 100 & 49 & 100 & 49 & 100 & 49 & 100 \\
\hline
\end{tabular}

*: Doğru cevap

Tablo incelendiğinde ön testte deney grubundaki öğrencilerin \%14.3’ü, kontrol grubundaki öğrencilerin ise $\% 24.5$ ' ; son testte ise deney grubundaki öğrencilerin \%61.2'si, kontrol grubundaki öğrencilerin ise \%38.8'i 1 ve 3 nolu devre çiftini seçerek doğru cevap vermiştir. Soruya doğru cevap veren öğrencilerden ön testte deney grubunda 5 öğrenci, kontrol grubunda 4 öğrenci; son testte deney grubundaki 
öğrencilerin \%55.1'i, kontrol grubundaki öğrencilerin ise \%20.4'ü 1 ve 3 nolu devre çiftini seçme nedenlerini doğru bir gerekçe ile desteklemiştir.

1 ve 3 nolu devreleri seçen öğrencilerin cevaplarında ifade ettikleri gerekçelerden bazı örnekler aşağıda sunulmuştur.

Pil sayısı ve lamba sayısı kategorisinde ön testte deney grubunda 5 öğrenci "Pil sayıları aynı, lamba sayıları farklı olduğu için”, kontrol grubunda 4 öğrenci "l'de 3 lamba, 1 pil; 3'de 1 lamba, 1 pil olduğu için", "Pil sayısı aynı lamba sayısı farklı olduğu için"; son testte deney grubunda 27 öğrenci "Pil sayıları aynı, lamba sayıları farklı olduğu için", kontrol grubunda 10 öğrenci "Pil sayısı aynı lamba sayısı farklı olduğu için”, "Lamba sayısı değişirken pil sayısı sabit kaldı̆̆ı için”" gerekçeleri ile 1 ve 3 nolu devre çiftini seçmiştir. Bu gerekçeler öğrencilerin bağımlı değişken üzerinde etkisi araştırılan değişkenin değiştirilirken etkisi kontrol altına alınması gereken değişkenin sabit tutulması gerektiğini bildiklerini ve bilgilerini farklı bir duruma transfer edebildiklerini göstermektedir. Lamba sayısının parlaklık üzerindeki etkisinin araştırıldığı bir deney için lamba sayısı bağımsız (değiştirilmesi gereken) değişken, pil sayısı ise kontrol altında tutulması gereken (sabit tutulması gereken) değişkendir. Öğrencilerin yaptıkları devre seçiminde bu duruma dikkat ettikleri görülmüştür.

Lamba sayısı kategorisinde ön testte kontrol grubunda 3 öğrenci "1'de lamba fazla olup, 3'de 1 lamba olduğu için”, "1'de fazla lamba olup, 3'de 1 lamba olduğu için”, "1. devre çok parlak, 3. devre lamba az olduğundan az parlayacă̆ için”; son testte deney grubunda 1 öğrenci " 1 . devreden 3. devreye geçişte lamba sayıs azalmıştır.", kontrol grubunda 3 öğrenci “1'de lamba fazla olup, 3'de 1 lamba olduğu için", "1'de fazla lamba olup, 3'de 1 lamba olduğu için”, "Birinde çok diğerinde az lamba olduğu için" gerekçeleri ile 1 ve 3 nolu devre çiftini seçmiştir. Öğrencilerde lamba sayısı azken parlaklığın az, lamba sayısı çokken parlaklığın fazla olacağına yönelik bir kavram yanılgısı mevcuttur. Bu yanılg1 "Devredeki Lambaların Yaydığ Toplam Işık Modeli” olarak adlandırılmıştır. Bu modele göre öğrenci basit elektrik devresinde yer alan lambaların ayrı ayrı yaydıkları 1şığı tek bir kaynaktan çıkıyormuş gibi düşünerek lamba sayısı arttıkça parlaklığın artacağına inanmaktadır. Ayrıca bazı öğrenciler bir odayı 3 lambanın, 1 lambadan daha fazla aydınlatacağını düşündüklerini ifade etmişlerdir.

Ön testte deney ve kontrol grubundaki birer öğrenci "Pil saylsl ve enerji az"; son testte kontrol grubunda 1 öğrenci pil sayısı ve enerji kategorisinde "1 pil 3 lambayı az aydınlatıp, 1 pil 1 lambayı daha iyi aydınlatacağı için”" gerekçeleri ile 1 ve 3 nolu devre çiftini seçmiştir. Bu durum öğrencilerin lamba parlaklığ 1 üzerinde sadece pil sayısının etkili olduğunu düşündüklerini ortaya koymaktadır. Lamba sayılarına dikkat etmeksizin pil sayısı üzerinde yoğunlaşan öğrencilerin pil sayısı az olan devre çiftini tercih etmeleri dikkat çekicidir. Öğrencilerde saptanan bu yanılg1 "Parlaklık Üzerindeki Tek Etki: Pil Sayısı Modeli” olarak adlandırılmıştır.

1 ve 2 nolu devreleri seçen öğrencilerin cevaplarında ifade ettikleri gerekçelerden bazı örnekler aşağıda sunulmuştur.

Lamba sayısı kategorisinde ön testte kontrol grubunda 2 öğrenci " 1 'de 3, 2 'de 2 lamba olduğu için”, son testte deney grubunda 2 öğrenci "Lamba saylsı farklı ve parlaklı̆̆ etkilediği için” gerekçesi ile 1 ve 2 nolu devreleri seçmiştir. Öğrencilerin yaptıkları seçimde dikkat çeken nokta 1 ve 2 nolu devrelerde pil sayılarının da farklı 
olmasıdır. Bu bulgu öğrencilerin parlaklıkla ilgili sadece lamba sayılarına bakarak karar verdiklerini ve lamba sayısını lamba parlaklığını etkileyen tek değişken olarak kabul ettiklerini ortaya koymaktadır. Öğrencilerde saptanan kavram yanılgısı "Parlaklık Üzerindeki Tek Etki: Lamba Sayısı Modeli” olarak adlandırılmıştır.

Pil sayısı ve enerji kategorisinde ön testte deney grubunda 1 ögrenci "Pil sayıs fazla olduğu için, tek pil az enerji üreteceği için", kontrol grubundaki 1 öğrenci ise " 1 . devreden 2. devreye geçerken pil sayısı, enerji artar." gerekçeleri ile 1 ve 2 nolu devre çiftini seçmiştir. Öğrenciler lamba sayılarına dikkat etmeksizin doğrudan pil sayıları üzerinde yoğunlaştıkları için lamba parlaklığı üzerinde etkili tek faktörün pil sayısı olduğunu düşünmektedir. Öğrencilerde saptanan kavram yanılgısı "Parlaklık Üzerindeki Tek Etki: Pil Sayısı Modeli” olarak adlandırılmıştır.

Parlaklık kategorisinde ön testte deney grubunda 1 öğrenci "Parlaklıkları diğerlerinden daha iyi olduğu için", kontrol grubunda 1 öğrenci ise "En parlak devreler oldukları için" gerekçeleri ile 1 ve 2 nolu devre çiftini seçmiştir. Soruda verilen devreler için parlaklık sıralaması olarak $4>2=3>1$ düşünüldüğünde 4 . devre tüm devrelerden daha parlaktır. Öğrenciler 1 ve 2 nolu devrelerin parlak olmasını lamba sayısının fazla olmasına bağlamışlardır. Bu öğrencilerde "Devredeki Lambaların Yaydığı Toplam Işık Modeli” olarak adlandırılan kavram yanılgısı mevcuttur. Bu yanılgıda öğrenci devredeki her lambanın ayrı ayrı yaydığı 1şı̆̆ı tek bir lambadan çıkıyormuş gibi düşünmektedir. Öğrenciler lamba sayısı arttıkça aydınlanmanın artacağına yönelik kavram yanılgısına sahiptir.

1 ve 4 nolu devreleri seçen öğrencilerin cevaplarında ifade ettikleri gerekçelerden bazı örnekler aşağıda sunulmuştur.

Lamba ve pil sayısı kategorisinde ön testte deney grubunda 5 öğrenci " 1 'de 3 lamba, 1 pil; 4'de 2 lamba, 3 pil olduğu için”, "2 ve 3'de pil sayısı=lamba sayıs olduğu için", "Pil ve lamba saylları farklı ve fazla olduğu için", kontrol grubunda 8 öğrenci "I'de 3 lamba, 1 pil; 4'de 2 lamba, 3 pil olduğu için”, "1'de pil az, lamba çok; 4'de pil çok, lamba az olduğu için"; son testte deney grubunda 3 öğrenci "Pil sayısl ve lamba sayısı kendi içinde aynı olmadĭ̆ ve fazla olduğu için”, kontrol grubunda 3 öğrenci ise "Pil saylsı ve lamba sayıs sadece bunlarda farklı ve fazla olduğu için" gerekçeleri ile 1 ve 4 nolu devre çiftini seçmiştir. Öğrencilerin gerekçelerinden 1 ve 4 nolu devreleri seçerken lamba ve pil sayılarının fazla olma durumuna dikkat ettikleri anlaşılmıştır. $\mathrm{Bu}$ seçimle ilgili gerekçelerinde lamba ve pil sayısının çok olduğu devrelerde lambanın parlak yanacağına ilişkin yaptıkları açıklamalar dikkat çekicidir. Bu durum öğrencilerde lamba sayısındaki değişime bağlı parlaklık konusunda ciddi bir yanılgı olduğunu ortaya koymaktadır. Ayrıca lamba parlaklığı üzerinde etkili olan iki değişkenin seçtikleri devrelerde farklı olması değişkenleri belirleme ve kontrol etme olarak adlandırılan bilimsel süreç becerisinin doğasına aykırı bir durumdur. $\mathrm{Bu}$ bulgudan öğrencilerin lamba parlaklığı hakkında yorum yaparken lamba sayısının ya da pil sayısının fazla olduğu devreleri seçecekleri anlaşılmaktadır. Pil sayısının fazla olduğu devreleri elektrik enerjisi fazla olacağı için, lamba sayısının fazla olduğu devreleri ise "Devredeki Lambaların Yaydığı Toplam Işık Modeli" temelinde aydınlanma fazla olacağı için tercih edeceklerini ifade etmişlerdir.

Ön testte kontrol grubunda 1 öğrenci pil sayısı kategorisinde " 1 . devrede pil az, 4. devrede pil en çok olduğu için I'de pilin enerjisi az, 4'de enerji fazla olur.” gerekçesi 
ile 1 ve 4 nolu devre çiftini seçmiştir. 1 ve 4 nolu devrelerde pil sayısı gibi lamba sayısı da farklıdır. Buna karşın öğrenci lamba sayısındaki farklılığı dikkate almaksızın pil sayıları üzerinde yoğunlaşarak seçim yapmıştır. Öğrencide "Parlaklık Üzerindeki Tek Etki: Pil Sayıs1 Modeli” yanılgısı mevcuttur.

Son testte kontrol grubundaki 1 öğrenci pilin vereceği 1ş1k kategorisinde " 1 pil 3 lambaya az ışılk verirken, 3 pil 2 lambaya çok ışık vereceği için. 1. devreden 4. devreye geçişte pil sayısı arttı̆̆ için pilin lambalara vereceği ışık artar." gerekçesi ile 1 ve 4 nolu devre çiftini seçmiştir. Bu öğrenci pilin devredeki rolüne ilişkin kavram yanılgısına sahiptir. Öğrenci lambaların yaydığı ışı̆̆ı onlara pilin verdiğini düşünmektedir. Bu yanılg1 öğrencinin lamba ve pilin devredeki rolü ile devrede gerçekleşen enerji dönüşümünü bilmemesinden kaynaklanmaktadır. Öğrencide "Işık Kaynağı Olarak Pil Modeli” ve "Enerji Dönüşüm Modeli” olarak adlandırılan kavram yanılgıları mevcuttur.

Enerji kategorisinde ön testte deney grubunda 2 öğrenci "1. devreden 4. devreye pil saylsı arttı̆̆ için enerji artar.", kontrol grubunda ise 1 öğrenci " 1 'de lambaya az. enerji giderken, 4'de lambaya çok enerji gideceği için" gerekçesi ile 1 ve 4 nolu devre çiftini seçmiştir. Bu seçim öğrencilerin parlaklık üzerinde etkili tek faktörün pil sayısı olduğunu kabul ettiklerini ortaya koymaktadır. Bu öğrencilerde "Parlaklık Üzerindeki Tek Etki: Pil Sayısı Modeli" kavram yanılgısı mevcuttur.

Ön testte deney ve kontrol gruplarından 2 öğrenci parlaklık kategorisinde " 1 . 'de pil az, 4. devrede pil en çok. 1. devreden 4. devreye geçişte parlaklık artar." gerekçesi ile 1 ve 4 nolu devre çiftini seçmiştir. Öğrenciler ifade ettikleri gerekçe ile bu devre çiftini seçerken sadece pil sayısına dikkat ettiklerini ortaya koymuşlardır. Yaptıkları seçimde lamba sayısını dikkate almayan öğrencilerde "Parlaklık Üzerindeki Tek Etki: Pil Sayısı Modeli” kavram yanılgısı saptanmıştır.

Genel olarak 1 ve 4 nolu devreleri seçen öğrenciler sadece pil sayısına dikkat etmişlerdir. Bu durum öğrencilerin lamba parlaklığı üzerinde lamba sayısının herhangi bir etkisi olmadığını düşündüklerini ortaya koymaktadır.

2 ve 3 nolu devreleri seçen öğrencilerin cevaplarında ifade ettikleri gerekçelerden bazı örnekler aşağıda sunulmuştur.

Lamba ve pil sayısı kategorisinde ön testte deney grubunda 2 öğrenci "Lamba sayısı ve pil sayısı aynı olduğu için”, "Kendi içlerinde lamba ve pil sayıları aynı olduğu için", kontrol grubunda 3 öğrenci "Kendi içlerinde lamba sayısı=pil sayısı olduğu için", "pil sayısı=lamba sayısı"; son testte deney ve kontrol grubunda 1'er öğrenci "Pil sayısı ve lamba sayısı eşit olduğu için” gerekçeleri ile 2 ve 3 nolu devre çiftini seçmiştir. Öğrenciler yapacakları devre çifti seçiminde iki ayrı devreyi karşılaştırmaları gerekirken her devreyi kendi içinde lamba ve pil sayısının eşit olma durumuna dikkat ederek karşılaştırmışlardır. Öğrencilerde lamba ve pil sayısının eşit olduğu durumda lamba parlaklıklarının karşılaştırılabileceğine dair kavram yanılgısı mevcuttur. Saptanan yanılgı öğrencilerin lamba ve pil sayılarının eşit olduğu devrelerde iki devrenin de eşit parlaklıkta olacağını bilmediklerini ortaya koyması açısından dikkat çekicidir. 2 lamba ve 2 pil olan devre ile 1 lamba ve 1 pil olan devrenin parlaklıkları birbirine eşit olduğu için devreler arasında lamba parlaklıklarının karşılaştırılması mümkün değildir.

Ön testte kontrol grubunda 2 öğrenci parlaklık kategorisinde "Eşit parlaklıkta yandıkları için” gerekçesi ile 2 ve 3 nolu devre çiftini seçmiştir. Öğrencilerin ifade ettikleri gerekçenin aksine iki devrenin de parlaklığının eşit olduğu durum için pil ya da 
lamba sayısının parlaklık üzerindeki etkisinin gözlemlenmesi mümkün değildir. Ayrıca 2 ve 3 nolu devrelerde lamba ve pil sayıları aynı anda değiştirilmiştir. Bu durum değişken türlerini belirleme olarak adlandırılan bilimsel süreç becerisinin doğasına aykırıdır. Bununla birlikte öğrenciler kendilerinden beklenenin aksine iki ayrı devreyi karşılaştırmaları gerekirken her devreyi kendi içinde lamba ve pil sayısı eşitliği bağlamında karşılaştırmışlardır.

2 ve 4 nolu devreleri seçen öğrencilerin cevaplarında ifade ettikleri gerekçelerden bazı örnekler aşağıda sunulmuştur.

Lamba ve pil sayısı kategorisinde ön testte deney ve kontrol gruplarından 2 öğrenci "Lamba sayısı aynı pil sayısı farklı olduğu için"; son testte ise deney grubundan 4 öğrenci "Pil sayısı değişik, lamba sayısı değişmemiş", kontrol grubundan 5 öğrenci "Lamba sayısı sabit olup pil sayısı değiş̧tiği için”, "Lamba sayıları eşitken pil sayıları eşit olmadığı için" gerekçeleri ile 2 ve 4 nolu devre çiftini seçmiştir. Öğrencilerin yaptıkları devre seçiminde soruda ifade edilenin aksine pil sayısının lamba parlaklığı üzerindeki etkisi gözlenebilir. Bu durum öğrencilerin bağımsız değişken ile kontrol edilen değişkeni karıştırdıklarını ortaya koyan bir bulgudur. Öğrencilerin değişken türlerini belirlemede ve beraberinde kontrol etmede güçlük yaşadıkları anlaşılmaktadır.

Pil sayısı ve parlaklık kategorisinde ön testte deney grubunda 3 öğrenci "Çok ışık saçacakları için”, kontrol grubunda 4 öğrenci "İkisi çok parlak olup daha çok ışık vereceği için", "Daha fazla parlak olduğu için"; son testte ise deney ve kontrol grubundan 1'er öğrenci ön testte "2. ve 4. devrede pil sayısı fazla olduğu için parlaklık fazla olur.", "2 ve 4, 1 ve 3'den daha parlak yanacağ için” gerekçeleri ile 2 ve 4 nolu devre çiftini seçmiştir. 4>2=3>1 sıralaması düşünüldüğünde 2 ve 3 'ün parlaklıklarının eşit olması nedeni ile en parlak devreler 2 ve 4 olamaz. Bu durum öğrencilerin sadece pil sayılarına bakarak parlaklıkla ilgili yorum yaptıklarını ortaya koyan önemli bir bulgudur. Öğrencilerde saptanan kavram yanılgısı "Parlaklık Üzerindeki Tek Etki: Pil Sayısı Modeli” olarak adlandırılmıştır.

Ön testte deney grubunda 3 öğrenci pilin lambalara vereceği 1şık kategorisinde "Lambanın parlak olması için pil sayısı fazla olmalı. Pil sayısı fazla olursa pilin lambalara vereceği ışık artar.” gerekçesi ile 2 ve 4 nolu devre çiftini seçmiştir. Bu gerekçe öğrencilerin pili bir elektrik enerjisi kaynağı olarak görmekten ziyade 1şık kaynağı olarak kabul ettiklerini ortaya koymaktadır. Ayrıca öğrencilerde basit elektrik devresinde elektrik enerjisinin $1 \mathrm{~s} 1$ ve 1 şı enerjisine dönüşümü konusunda ciddi bir kavram yanılgısı olduğu anlaşılmıştır. Öğrencilerde saptanan bu yanılgılar "Işık Kaynağı Olarak Pil Modeli” ve "Enerji Dönüşüm Modeli” olarak adlandırılmıştır.

Ön testte deney grubundaki 1 öğrenci "Lamba sayısı lamba parlaklı̆̆ını etkilemeyeceği için” gerekçesi ile devrelerden herhangi birini seçmeyeceğini ifade etmiştir. Bu öğrenci lamba sayısının parlaklık üzerinde etkili olmadığını düşünmektedir. $\mathrm{Bu}$ düşünce öğrencinin pili parlaklık üzerinde etkili olan tek değişken olarak görmesinden kaynaklanıyor olabilir. Öğrencide "Parlaklık Üzerindeki Tek Etki: Pil Sayısı Modeli" olarak adlandırılan kavram yanılgısı mevcuttur. Öğrenci elektrik devresinde sadece pil sayısının değiştiği durum için parlaklığın değişeceğini lamba sayısındaki değişimin parlaklığı etkilemeyeceğini ifade etmiştir. Bu yanılgı kendi içinde pili sabit akım kaynağı olarak düşünme yanılgısını da içermektedir. Öyle ki bu yanılgıda 
öğrenci pili devreye her durumda aynı akımı veren bir eleman olarak düşünür. Lamba eklendiğinde akımın değişmeyeceğini düşünen öğrenci her durumda lambalardan aynı akımın geçeceğine inandığı için lamba sayısının parlaklık üzerinde herhangi bir etkisi olmadığını düşünür. Pilin sabit akım üreten bir kaynak olarak düşünüldüğüne dair kavram yanılgısı alanyazında "Sabit Akım Kaynağı Modeli” olarak ifade edilmektedir.

\section{Sonuç ve Tartışma}

Araştırma sonucunda lamba parlaklığı konusunda değişkenleri belirleme ve kontrol etmenin öğretiminde deney grubunda kullanılan analojiyle kontrol grubuna nazaran daha başarılı sonuçlar elde edilmiştir. Bu başarılı sonuçlar üzerinde analoji ile gerçekleştirilen öğretimin ilgi ve dikkatleri konu üzerinde yoğunlaştırmasının, dersi eğlenceli hale getirmesinin etkili olduğu düşünülmektedir. Alanyazında ortaokul öğrencileri ile gerçekleştirilen çalışmalarda da öğretim sürecinde analoji kullanımının akademik başarı (Demirci-Güler \& Yağbasan, 2010; Erökten \& Kahraman-Gökharman, 2013; Eskandar, Bayrami, Vahedi, \& Ansar, 2013; Kobal, Şahin, \& Kara, 2013; ŞekerGökulu \& Geban, 2014), öğrenme (Blake, 2004; Çakır \& Azizoğlu, 2012; Çıray \& Erişti, 2014; Glynn \& Takahashi, 1998; Şaşmaz-Ören, Ormancı, Babacan, Çiçek, \& Koparan, 2010), kavrama (Şenpolat, Seven, \& Düzgün, 2005) ve kavramsal anlamayı (Blake, 2004; Wichaidit, Wongyounoi, Dechsri, \& Chaivisuthangkura, 2011) olumlu etkilediği saptanmıştır.

Araştırma sonucunda lamba parlaklığı üzerinde etkili olan faktörlerdeki değişimle ilgili olarak parlaklığın sadece pil sayısındaki değişimden etkilendiğini ve lamba sayısının parlaklık üzerinde herhangi bir etkisi olmadığını düşünme; bu durumun aksine lamba parlaklığının sadece lamba sayısındaki değişimden etkilendiğini ve pil sayısının parlaklık üzerinde herhangi bir etkisi olmadığına ilişkin bilimsel açıdan doğru olmayan düşünceler saptanmıştır. Saptanan bu yanılgılar "Parlaklık Üzerindeki Tek Etki: Pil Sayısı Modeli" ve "Parlaklık Üzerindeki Tek Etki: Lamba Sayısı Modeli" olarak adlandırılmıştır.

Lamba parlaklığını sadece pil sayısındaki değişimin etkileyeceğini düşünen öğrenciler için iki ayrı devrede yer alan lambaların sayısının aynı ya da farklı olması önemli değildir. Öyle ki, bu şekilde düşünen öğrenciler için pil lambanın 1şık vermesini sağlayan devre elemanıdır ve sadece pil sayısındaki değişime bağlı olarak parlaklık değişir. Lamba sayısındaki değişimin parlaklık üzerinde herhangi bir etkisinin olmadığına yönelik düşüncenin öğrencilerin pilin elektrik enerjisinin lambalar arasında paylaşıldığına dikkat etmemelerinden kaynaklanabileceği düşünülmektedir. Öğrenciler pilin devredeki tüm lambalara lamba sayısı artsa da azalsa da sabit değerde enerji vereceğini düşünmektedir. Bu kavram yanılgısına benzer şekilde alanyazında "Sabit Akım Kaynağı Modeli” olarak adlandırılan modelde de güç kaynağı devrenin kurulum şeklinden bağımsız olarak bağlandığı devrede sabit bir akım kaynağı olarak algılanmaktadır. Bu yanılgı ortaokul öğrencileri (Cheng \& Kwen, 1998), lise öğrencileri (Demirezen \& Yağbasan, 2013; Karakuyu \& Tüysüz, 2011; Korganci, Miron, Dafinei, \& Antohe, 2015; Küçüközer, 2003; Küçüközer \& Kocakülah, 2007; Sencar \& Eryılmaz, 2002, 2004; Sencar, Yılmaz, \& Eryılmaz, 2001; Shipstone ve diğerleri, 1988; Taşlıdere \& Eryılmaz, 2009; Yıldırım, Yalçın, Şensoy, \& Akçay, 2008; Yılmaz \& HuyugüzelÇavaş, 2006), lise ve üniversite öğrencileri (Engelhardt \& Beichner, 2004), ortaokul birinci sınıftan üniversite son sınıfa kadar öğrenciler (Dupin \& Johsua, 1987), fen bilgisi 
öğretmen adayları (Altun, 2009; Ateş \& Polat, 2005; Taşlıdere, 2014; Yumuşak, 2008), fizik öğretmenleri (Cohen, Eylon, \& Ganiel, 1983; Küçüközer \& Demirci, 2005), ilkortaokul öğretmenleri (Heller \& Finley, 1992) ile yapılan çeşitli çalışmalarda ortaya koyulmuştur.

Lamba parlaklığını sadece lamba sayısındaki değişimin etkileyeceğini düşünen öğrenciler için iki ayrı devrede yer alan pillerin sayısının aynı ya da farklı olması önemli değildir. Öyle ki, bu şekilde düşünen öğrenciler için sadece lamba sayısındaki değişime bağlı olarak parlaklık değişir ve lamba sayısındaki değişim ile parlaklık arasında doğru orantılı bir ilişki vardır. Bu kavram yanılgısı öğrencilerin gerek yazılı cevaplarında gerekse görüşmelerde ifade ettikleri üzere devrede yer alan tüm lambaların tek bir sşık kaynağı gibi algılanmasından kaynaklanmaktadır. Öğrencilerde "Ne kadar çok lamba olursa o kadar büyük bir ışık açığa çıkar." düşüncesi hâkimdir. Benzer şekilde Ayvacı ve İpek-Akbulut (2012) tarafından ortaokul öğrencileri ile yapılan çalışmada da lamba sayısının artışı ile lamba parlaklığının artacağına ilişkin kavram yanılgısı ortaya koyulmuştur.

Devrede gerçekleşen enerji paylaşımı ile ilgili olarak pilin enerjisinin lambalar arasında paylaşıldığının göz ardı edildiği; pilin sabit bir akım kaynağı olarak kabul edilmesi nedeni ile her durumda lambadan aynı değerde akım geçeceğine ve lamba sayısındaki değişimin parlaklığı etkilemeyeceğine inanıldığı saptanmıştır. Saptanan bu yanılg1 "Lamba Başına Düşen Enerji Modeli" olarak adlandırılmıştır.

Devrede yer alan lambaların bağımsız bir 1şık kaynağı olarak algılanması gerekirken devredeki tüm lambaların tek bir 1şık kaynağı olarak görülmesi nedeni ile lamba sayısındaki artışla birlikte yayılan toplam 1şığında artacağının düşünüldüğü belirlenmiştir. Saptanan bu yanılg1 "Devredeki Lambaların Yaydığ1 Toplam Işık Modeli” olarak adlandırılmıştır. Kavram yanılgısı öğrencilerin basit bir elektrik devresinde bağlı olan lambaların ayrı ayrı yaydıkları ışığı zihinlerinde tek bir lambadan çıkıyormuş gibi düşünmelerinden kaynaklanmaktadır. Öyle ki, kavram yanılgısı öğrencilerin görüşmelerde de ifade ettikleri üzere " $\ddot{c ̧ ~ l a m b a ~ o d a y ı ~ b i r ~ l a m b a d a n ~ d a h a ~}$ çok aydınlatır.” düşüncesine dayanmaktadır. Öğrenciler lamba sayısı arttıkça toplam lamba sayısındaki artış ile birlikte yayılan ışığın ve parlaklığın da artacağına inanmaktadır. Benzer şekilde alanyazında da ortaokul öğrencileri ile yapılan bir çalışmada lamba sayısı arttığında parlaklığın artacağına ilişkin kavram yanılgısı ifade edilmektedir (Ayvacı \& İpek-Akbulut, 2012).

Devrede gerçekleşen enerji dönüşümlerinin bilinmediği bu nedenle de pilin doğrudan bir 1şık kaynağı olarak algılandığı saptanmıştır. Saptanan bu yanılgılar "Işık Kaynağı Olarak Pil Modeli” ve "Enerji Dönüşümü Modeli” olarak adlandırılmıştır. Kavram yanılgısının temelinde "Pil sayısı arttıkça pilin lambalara vereceği ışı k artar." düşüncesi yer almaktadır. Pilin lambalara doğrudan 1şık veren bir devre elemanı olarak görülmesinin pilin devredeki görevinin ve devrede gerçekleşen enerji dönüşümünün bilinmemesinden kaynaklanıyor olabileceği düşünülmektedir. Benzer şekilde alanyazında da ortaokul öğrencileri ile gerçekleştirilen bir çalışmada pilin 1 şı verebileceğine dair kavram yanılgısı içeren düşünce ortaya koyulmuştur (Cheng \& Kwen, 1998).

Devredeki lambaların aynı anda değil de sıralı olarak yandığının düşünülmesi nedeni ile lamba sayısındaki değişimin sadece lambaların ışı verme süresini 
etkilediğine inanıldığı anlaşılmıştır. Bu yanılg1 "Lamba Sayısına Bağlı Işık Verme Süresi Modeli" olarak adlandırılmıştır. Bu durumda lamba sayısı ile lambanın ışık verme süresi arasında ilişki kurulmuştur. Yapılan görüşmelerde de kurulan ilişki "Lamba sayısı arttıkça lambanın yanma süresi artar. Önce ilk lamba yanar tükenir. Sonra ikinci lamba yanmaya başlar ve süre uzun olur." ifadesi ile gerekçelendirilmiştir. Devreye seri bağlanan lambalardan önce birinin yanacağı, bu lambanın tamamen tükenince söneceği, ardından diğer lambanın yanmaya başlayacağı ve böylece devrenin daha uzun süre 1 şık vereceği düşünülmektedir. $\mathrm{Bu}$ modelde lamba sayısı arttıkça devrenin daha uzun süre 1şık vereceğine inanılmaktadır.

Pil sayısı ile parlaklık arasında kurulan ilişkide pil sayısı ile lamba parlaklığı arasında ters orantı olduğunun düşünüldüğü tespit edilmiştir. Bu yanılg1 "Pil Sayıs1Parlaklık İlişkisi Modeli” olarak adlandırılmıştır.

Değişken türlerinin birbiri ile karıştırıldığg, hangi değişkenin değiştirilip hangisinin kontrol edilmesi gerektiği hususunda güçlük yaşandığı saptanmıştır. Bu yanılg1 "Değişkeni Belirleme ve Kontrol Etme Modeli" olarak adlandırılmıştır. Bu model değişken türlerinden bağımsız ve kontrol edilen değişkeni yanlış tayin etme ve beraberinde de değişkenlerden hangisinin değiştirilip hangisinin kontrol edileceğine karar vermede bilimsel açıdan doğru olmayan seçimler yapmayı kapsamaktadır.

Devrelerin kendi aralarında çiftler halinde karşılaştırılması gerekirken her devrenin kendi içinde lamba ve pil sayıları bağlamında karşılaştırıldığı görülmüştür. Devrelerin parlaklıkları ile ilgili olarak en parlak olarak nitelendirilen devre çiftlerinin aslında en parlak devreler olmadıkları anlaşılmıştır.

$\mathrm{Bu}$ araştırmada öğretim öncesinde her iki grupta da saptanan ve yukarıda ifade edilen kavram yanılgılarının öğretim sonunda giderilmesi ve yeni kavram yanılgısı oluşumunun önlenmesinde deney grubunda kontrol grubuna nazaran daha başarılı sonuçlar elde edilmiştir. Benzer şekilde alanyazında yer alan çalışmalarda da analojilerin kavram yanılgılarının giderilmesinde etkili olduğu ortaya koyulmuştur (Abak, Eryılmaz, Y1lmaz, \& Y1lmaz, 2001; Aykutlu \& Şen, 2011; Bilgin \& Geban, 2001; Clement, 1998, Dilber \& Düzgün, 2008; Korganci ve diğerleri, 2015; Paatz, Ryder, Schwedes, \& Scott, 2004; Pabuçcu \& Geban, 2006; Şendur, Toprak, \& ŞahinPekmez, 2008; Tsai, 1999).

\section{Öneriler}

Basit elektrik devresinde lamba ve pil sayılarındaki değişimin parlaklık üzerindeki etkisi kurulacak devreler ve bu devreleri temsil edebilecek nitelikte analojiler kullanılarak uygulamalı olarak gösterilmelidir. Ayrıca bireylerin yaşamda karşılaştıkları bir problemi kuracakları hipotezleri test ederek çözebilecekleri düşünüldüğünde hipotez test etmede değişkenleri belirleme ve kontrol edebilme becerilerinin kazanılması gereklidir. Öğrencilerin kendilerine verilen bir durumla ilgili bağımlı, bağımsız ve kontrol edilen değişkenleri belirleyebilmeleri ve bir sonraki adımda da sonuca ulaşabilmeleri için değişkenleri kontrol edebilmeleri son derece önemlidir. Bu nedenle değişkenleri belirlemenin öğretiminde klasik alışılagelmiş düzenekler ya da öğretim araçları yerine daha ilgi çekici ve eğlenceli etkinliklerle ders işlenmeli ve dikkat çekici materyaller kullanılarak somut uygulamalar yapılmalıdır. 


\section{Summary}

Purpose and Significance: Students are activated and gained learning responsibility and research skills by scientific process skills. These skills provide easy and permanent learning. These skills are divided into basic, causal and experimental. Basic skills: observing, measuring, classifying, recording data, establishing number and space relations. Causal skills: predicting, identifying variables, deducing (predicting). Experimental skills: building hypothesis, modeling, experimenting, changing and controlling variables, making decisions (Akdeniz, 2011). Identifying variables that is one of the scientific process skills, is used both in science and physics courses and in all areas of life (Temiz \& Tan, 2009). Identifying variables involves determining all factors that are effective on a situation or event, and recognizing the characteristics of the factors that change or stay constant under the different conditions. Identifing and testing variables that are effective on an event, is very important in the research process (Akdeniz, 2011). A result can be affected by many variables. Other variables should be determined and the experimental setup should be set accordingly, for understanding the cause of the consequences or seeing the effects that any changes will have on the result. Because of this, defining variables and identifing elements that need to be controlled or fixed in experiments, is extremely important (Bozkurt \& Olgun, 2005).

However, when literature was examined, it was observed that participants confused dependent, independent, and controlled variables; it was seen that students' ability identifing variables was insufficient. These results may cause that students give scientifically inaccurate answers about variables which are changed or kept constant. The results of studies in the literature emphasizes that interesting and entertaining activities with remarkable instructional materials should be made on the teaching of identifying and controlling variables. One of these instructional materials is analogies.

Analogies are strong links between the similarities of concepts, principles and formulas. These links are strong bridges between the preliminary information (source) and the new information (target) (Kesercioğlu et al., 2004). Analogies facilitate the structuring process of information; analogies make understandable conceptual change; analogies bring new perspectives to the individual through conceptual change; analogies facilitate the abstract meaning by drawing attention to the similarities between the subject and the real world; analogies visualize concepts; analogies attract the individual's interest and motivate the individual. Analogies are powerful materials that can be used in teaching (Duit, 1991). Memory is made ready for new information by analogies (Gentner, 1983). Analogies facilitate learning by knowing the domains of the target concept. Besides these, analogies are effective in determining preliminary information and misconceptions (Duit, 1991). For this reason, it is aimed to investigate the effects of the analogy on teaching of identifying and controlling variables on the brightness of a bulb.

Methods: The study was conducted with the participation of 98 fifth grade students. 49 students were in the experimental group and 49 students were in the control group. The unmatched control group pretest and posttest method was used in this study, interviews were done with the students.

Analogy was used in the experimental group and analogy was not used in the control group. Pilot application was done with 25 fifth grade students. The same teacher taught 
lessons in the experimental group and control group. The researcher participated to all lessons of experimental group and control group as an observer. The researcher made preliminary study with teacher in 15-20 minutes. The researcher informed to teacher about application. Application took 11 lesson hours. Application was done to teach about factors that depend on the brightness of a bulb; effects of battery's number and bulb's number on brightness; dependent, independent and controlled variables by making comparisons between PSM 1-2-3 and BED 1-2-3 in the experimental group. Teacher taught lessons without using analogy (PSM) in the control group.

A data collection tool consisting of two questions was prepared by examining national and international literature and curriculum. Expert opinions were taken about data collection tool. Pilot application was made with 42 sixth grade students. As a result of expert opinions and pilot application, data collection tool was finalized. Data collection tool were employed to experimental group and control group as a pre-test and a posttest. The data obtained during the study were analyzed using the content analysis method. Direct quotations from students' answers were given.

Results: Circuit pair is suitable for examining the effect of battery's number on the brightness of a bulb: $34.7 \%$ of the students in the experimental group and $26.5 \%$ of the students in the control group at pre-test; $71.4 \%$ of the students in the experimental group and $42.9 \%$ of the students in the control group at post-test gived correct answer. For this question, $12.2 \%$ of the students in the experimental group and $4.1 \%$ of the students in the control group at pre-test; $46.9 \%$ of the students in the experimental group and $24.5 \%$ of the students in the control group at post-test expressed correct reasons for their answers.

Circuit pair is suitable for examining the effect of bulb's number on the brightness of a bulb: $14.3 \%$ of the students in the experimental group and $24.5 \%$ of the students in the control group at pre-test; $61.2 \%$ of the students in the experimental group and $38.8 \%$ of the students in the control group at post-test gived correct answer. For this question, 5 students in the experimental group and 4 students in the control group at pre-test; $55.1 \%$ of the students in the experimental group and $20.4 \%$ of the students in the control group at post-test expressed correct reasons for their answers.

Discussion and Conclusions: As a result of research, successful results were obtained by using analogy (PSM) in the experimental group in terms of teaching of identifying and controlling variables on the brightness of a bulb. In this research, successful results were obtained in the experimental group in terms of eliminating misconceptions and preventing the formation of new misconceptions. 


\section{Kaynakça}

Abak, A., Eryılmaz, A., Y1lmaz, S., \& Y1lmaz, M. (2001). Effects of bridging analogies on students' misconceptions about gravity and inertia. Hacettepe Üniversitesi Ĕ̈itim Fakültesi Dergisi, 20, 1-8.

Akdeniz, A. R. (2011). Problem çözme, bilimsel süreç ve proje yönetiminin fen eğitiminde kullanımı. İçinde S. Çepni (Ed.), Kuramdan uygulamaya fen ve teknoloji ögrretimi (ss. 154-179). Ankara: Pegem Akademi.

Altun, S. (2009). Üç aşamalı bir testle fen bilgisi öğretmen adaylarının basit elektrik devreleri konusundaki kavram yanılgılarının tespiti. Bayburt Üniversitesi Ĕgitim Fakültesi Dergisi, 4(1-2), 72-79.

Anagün, Ş. S., \& Yaşar, Ş. (2009). İlköğretim beşinci sınıf fen ve teknoloji dersinde bilimsel süreç becerilerinin geliştirilmesi. İlköğretim Online, 8(3), 843-865.

Ateş, S. (2005). Öğretmen adaylarının değişkenleri belirleme ve kontrol etme yeteneklerinin geliştirilmesi. Gazi Üniversitesi Gazi Ĕ̌itim Fakültesi Dergisi, 25(1), 21-39.

Ateş, S., \& Bahar, M. (2002, 16-18 Eylül). Araştırmacı fen öğretimi yaklaşımıyla sınıf öğretmenliği 3. sınıf öğrencilerinin bilimsel yöntem yeteneklerinin geliştirilmesi. V. Ulusal Fen Bilimleri ve Matematik Eğitimi Kongresi, ODTÜ, Ankara.

Ateş, S., \& Polat, M. (2005). Elektrik devreleri konusundaki kavram yanılgılarının giderilmesinde ögrrenme evreleri metodunun etkisi. Hacettepe Üniversitesi Ĕ̈itim Fakültesi Dergisi, 28, 39-47.

Ayas-Kör, S. (2006). İlköğretim 5. sınıf öğrencilerinde "Yaşamımızdaki Elektrik" ünitesinde görülen kavram yanılgılarının giderilmesinde bütünleştirici ögrenme kuramına dayalı geliştirilen materyallerin etkisi (Yüksek lisans tezi). Karadeniz Teknik Üniversitesi Fen Bilimleri Enstitüsü, Trabzon.

Aydoğdu, B. (2012, 27-30 Haziran). Fen bilgisi öğretmen adaylarının hipotez kurma ile değişkenleri belirleme ve kontrol etme becerilerinin incelenmesi. X. Ulusal Fen Bilimleri ve Matematik Ĕ̈itimi Kongresi, Niğde.

Aykutlu, I., \& Şen, A. İ. (2011). Lise öğrencilerinin elektrik akımı konusundaki kavram yanılgılarının belirlenmesinde ve giderilmesinde analojilerin kullanılması. Necatibey Ĕgitim Fakültesi Elektronik Fen ve Matematik Eğitimi Dergisi (EFMED), 5(2), 221-250.

Ayvacı, H. Ş., \& İpek-Akbulut, H. (2012). Elektrik akımı ile ilgili kavramların gelişiminde $\mathrm{V}$ diyagramlarının etkisini belirlemeye yönelik bir pilot çalışma. Erzincan Üniversitesi Eğitim Fakültesi Dergisi, 14(1), 106-123.

Bağcı-Kılıç, G., Yardımcı, E., \& Metin, D. (2009). Fen öğretiminde değişkenler nasıl adlandırılabilir? Abant İzzet Baysal Üniversitesi Dergisi, 9(2), 13-26.

Bilgin, İ., \& Geban, Ö. (2001). Benzeşim (analoji) yöntemi kullanarak lise 2. sınıf ögrencilerinin kimyasal denge konusundaki kavram yanılgılarının giderilmesi. Hacettepe Üniversitesi Ĕ̈itim Fakültesi Dergisi, 20, 26-32.

Blake, A. (2004). Helping young children to see what is relevant and why: Supporting cognitive change in earth science using analogy. International Journal of Science Education, 26(15), 1855-1873. 
Bostan-Sarığlan, A., Gedik, İ., \& Can, Y. (2016). Ortaokul öğrencilerinin bilimsel süreç becerilerinin karşılaştırılması: Kuvvet ve hareket ünitesi örneği. Mersin Üniversitesi Ĕ̆itim Fakültesi Dergisi, 12(2), 689-701.

Bozkurt, O., \& Olgun, Ö. S. (2005). Fen ve teknoloji eğitiminde bilimsel süreç becerileri. İçinde M. Aydoğdu ve T. Kesercioğlu (Ed.), İlköğretimde fen ve teknoloji ögrretimi (ss. 56-70). Ankara: Anı Yayıncılık.

Böyük, U., Tanık, N., \& Saraçoğlu, S. (2011). İlköğretim ikinci kademe öğrencilerinin bilimsel süreç beceri düzeylerinin çeşitli değişkenler açısından incelenmesi. TÜBAV Bilim, 4(1), 20-30.

Cheng, A. K., \& Kwen, B. H. (1998). Primary pupils' conceptions about some aspects of electricity.Retrieved from http://www.aare.edu.au/data/publications/1998/ang98205.pdf

Clement, J. J. (1998). Expert novice similarities and instruction using analogies. International Journal of Science Education, 20(10), 1271-1286.

Cohen, R., Eylon, B., \& Ganiel, U. (1983). Potential differences and current in simple electric circuits: A study of students' concepts. American Journal of Physics, 51(5), 407- 412.

Çakır, C., \& Azizoğlu, N. (2012, 4-7 Mayıs). Maddeyi oluşturan tanecikler konusunun analojilerle destekli öğretiminin öğrencilerin akademik başarısına etkisi. IV. Uluslararası Türkiye Eğitim Araştırmaları Kongresi, İstanbul.

Çıray, F., \& Erişti, B. (2014). Disiplinler arası analoji tabanlı öğretimin farklı düzeylerde akademik başarılı ilköğretim öğrencilerinin fen ve teknoloji dersi öğrenme düzeyleri üzerindeki etkisi. Illköğretim Online, 13(3), 1049-1064.

Demirci-Güler, M. P., \& Yağbasan, R. (2010, 27-29 October). Fen ve teknoloji dersinde analoji kullanımının öğrencilerin başarı, tutum ve bilgilerinin kalıcılığına etkisi. International Science and Technology Conference, Turkish Republic of Northern Cyprus.

Demirezen, S., \& Yağbasan, R. (2013). 7E modelinin basit elektrik devreleri konusundaki kavram yanılgıları üzerine etkisi. Hacettepe Üniversitesi Ĕ̆itim Fakültesi Dergisi, 28(2), 132-151.

Dilber, R., \& Düzgün, B. (2008). Effectiveness of analogy on students' success and elimination of misconception. Latin-American Journal of Physics Education, 2(3), 174-183.

Duit, R. (1991). On the role of analogies and metaphors in learning science. Science Education, 75(6), 649-672.

Dupin, J. J., \& Johsua, S. (1987). Conceptions of French pupils concerning electric circuits: Structure and evolution. Journal of Research in Science Teaching, 24(9), 791-806.

Durmaz, H., \& Mutlu, S. (2012). 7. sınıf öğrencilerinin bilimsel süreç becerilerini geliştirmeye yönelik bir çalışma örneği. Necatibey Ĕ̆itim Fakültesi Elektronik Fen ve Matematik Eğitimi Dergisi (EFMED), 6(1), 124-150.

Engelhardt, P. V., \& Beichner, R. J. (2004). Students' understanding of direct current resistive electrical circuits. American Journal of Physics, 72(1), 98-115. 
Erökten, S., \& Kahraman-Gökharman, H. (2013). The effect of analogy method on student achievement in the unit "The Structure and Properties of Matter" Çivril sample. World Applied Sciences Journal, 23(6), 744-750.

Eskandar, F. A., Bayrami, M., Vahedi, S., \& Ansar, V. A. A. (2013). The effect of instructional analogies in interaction with logical thinking ability on achievement and attitude towards chemistry. Chemistry Education: Research and Practice, 14, 566-575.

Gentner, D. (1983). Structure-mapping: A theoretical framework for analogy. Cognitive Science, 7(2), 155-170.

Glynn, S. M., \& Takahashi, T. (1998). Learning from analogy-enhanced science text. Journal of Research in Science Teaching, 35(10), 1129-1149.

Griffiths, A. K., \& Thompson, J. (1993). Secondary school students' understandings of scientific process: An interview study. Research in Science \& Technological Education, 11(1), 15-26.

Güden, C., \& Timur, B. (2016). Ortaokul öğrencilerinin bilimsel süreç becerilerinin incelenmesi (Çanakkale örneği). Abant İzzet Baysal Üniversitesi Ĕ̈itim Fakültesi Dergisi, 16(1), 163-182.

Harman, G., \& Çökelez, A. (2015). Teaching the effect of variables on the brightness of a light bulb in a simple electrical circuit using a pneumatic system model (PSM). International Journal of Physical Sciences, 10(6), 215-221.

Harman, G., \& Çökelez, A. (2016, 19-22 Mayıs). Fen bilgisi öğretmen adaylarının bilimsel süreç becerilerini anlama düzeylerinin belirlenmesi: Elektromıknatısın çekim gücü örneği. International Conference on Education in Mathematics, Science \& Technology (ICEMST 2016), Bodrum.

Heller, M. P., \& Finley, N.F. (1992). Variable uses of alternative conceptions, a case study in current electricity. Journal of Research in Science Teaching, 29(3), 259275.

Karakuyu, Y., \& Tüysüz, C. (2011). Elektrik konusunda kavram yanılgıları ve kavramsal değişim yaklaşımı. Gaziantep Üniversitesi Sosyal Bilimler Dergisi, 10(2), 867-890.

Karar, E. E., \& Yenice, N. (2012). İlköğretim 8. sınıf öğrencilerinin bilimsel süreç beceri düzeylerinin bazı değişkenler açısından incelenmesi. Ç. Ü. Sosyal Bilimler Enstitüsü Dergisi, 21(1), 83-100.

Keser, Ö. F., \& Başak, M. H. (2013). Yaşamımızdaki elektrik ünitesine yönelik öğrenci kazanım düzeylerinin incelenmesi. Türk Fen Ĕ̈itimi Dergisi, 10(2), 116-137.

Kesercioğlu, T., Yılmaz, H., Huyugüzel-Çavaş, P., \& Çavaş, B. (2004). İlköğretim fen bilgisi öğretiminde analojilerin kullanımı: "Örnek uygulamalar”. Ege Eğitim Dergisi, 5, 35-44.

Kobal, S., Şahin, A., \& Kara, İ. (2013). Fen ve teknoloji dersinde analojilere dayalı öğretimin öğrencilerin başarıları ve hatırda tutma düzeyi üzerindeki etkisi. Buca Ĕ̈itim Fakültesi Dergisi, 36, 46-61.

Korganci, N., Miron, C., Dafinei, A., \& Antohe, S. (2015). The Importance of InquiryBased Learning on Electric Circuit Models for Conceptual Understanding. WCES 2014, Procedia - Social and Behavioral Sciences, 191, 2463-2468. 
Küçüközer, H. (2003). Lise 1 öğrencilerinin basit elektrik devreleri konusuyla ilgili kavram yanılgıları. Hacettepe Üniversitesi Ĕ̆itim Fakültesi Dergisi, 25, 142148.

Küçüközer, H., \& Demirci, N. (2005, 13-16 September). High school physics teachers' forms of thought about simple electric circuits. 23 $3^{\text {th }}$ International Physics Congress, Muğla.

Küçüközer, H., \& Kocakülah, S. (2007). Secondary school students' misconceptions about simple electric circuits. Journal of Turkish Science Education, 4(1), 101115.

Laçin-Şimşek, C. (2010). Sınıf öğretmeni adaylarının fen ve teknoloji ders kitaplarındaki deneyleri bilimsel süreç becerileri açısından analiz edebilme yeterlilikleri. İlkögrretim Online, 9(2), 433-445.

Ocak, İ., \& Tümer, H. (2014). İlköğretim 5. sınıf öğrencilerinin bilimsel süreç becerilerine sahip olma düzeyleri (afyonkarahisar ili örneği). Afyon Kocatepe Üniversitesi Fen ve Mühendislik Bilimleri Dergisi, 14, 1-21.

Paatz, R., Ryder, J., Schwedes, H., \& Scott, P. (2004). A case study analysing the process of analogy-based learning in a teaching unit about simple electric circuits. International Journal of Science Education, 26(9), 1065-1081.

Pabuçcu, A., \& Geban, Ö. (2006). Remediating misconceptions concerning chemical bonding through conceptual change text. Hacettepe University Journal of Education, 30, 184-192.

Saka, A. (2012, 27-30 Haziran). Öğretmen adaylarının nedensel süreç becerileri açısından değerlendirilmesi. X. Ulusal Fen Bilimleri ve Matematik Eğitimi Kongresi, Niğde.

Sencar, S., \& Eryılmaz, A. (2002, 16-18 Eylül). Dokuzuncu sınıf öğrencilerinin basit elektrik devreleri konusuna ilişkin kavram yanılgıları. V. Ulusal Fen Bilimleri ve Matematik Ĕ̈itimi Kongresi, ODTÜ, Ankara.

Sencar, S., \& Eryılmaz, A. (2004). Cinsiyetin öğrencilerin elektrik konusunda sahip oldukları kavram yanılgıları üzerindeki etkisi ve görülen cinsiyet farklılıklarının nedenleri. Hacettepe Üniversitesi Ĕ̌itim Fakültesi Dergisi, 26, 141-147.

Sencar, S., Yılmaz, E. E., \& Eryılmaz, A. (2001). Lise öğrencilerinin basit elektrik devreleri ile ilgili kavram yanılgıları. Hacettepe Üniversitesi Eğitim Fakültesi Dergisi, 21, 113-120.

Shipstone, D. M., Rhöneck, C. V., Jung, W., Karrqvist, C., Dupin, J-J., Johsua, S., \& Licht, P. (1988). A study of students' understanding of electricity in five European countries. International Journal of Science Education, 10(3), 303-316.

Şaşmaz-Ören, F., Ormancı, Ü., Babacan, T., Çiçek, T., \& Koparan, S. (2010). Analoji ve araştırma temelli öğrenme yaklaşımına dayalı rehber materyal uygulaması ile buna yönelik öğrenci görüşleri. Batı Anadolu Eğitim Bilimleri Dergisi, 1(1), 3353.

Şeker-Gökulu, A., \& Geban, Ö. (2014). Facilitating conceptual change in atom, molecule, ion and matter concepts. Dicle Üniversitesi Ziya Gökalp Ĕ̈itim Fakültesi Dergisi, 23, 304-322. 
Şen, A. Z., \& Nakiboğlu, C. (2012).Ortaöğretim kimya ders kitaplarının bilimsel süreç becerileri açısından incelenmesi. Ahi Evran Üniversitesi Kırşehir Ĕgitim Fakültesi Dergisi (KEFAD), 13(3), 47-65.

Şendur, G., Toprak, M., \& Şahin-Pekmez, E. (2008). Buharlaşma ve kaynama konularındaki kavram yanılgılarının önlenmesinde analoji yönteminin etkisi. Ege Ë̆itim Dergisi, 9(2), 37-58.

Şenpolat, Y., Seven, S., \& Düzgün, B. (2005). Fen bilgisi öğretiminde analoji kullanımının öğrenci başarısına ve derse yönelik tutumlarına etkisinin araştırılması. Çukurova Üniversitesi Eğitim Fakültesi Dergisi, 31(2), 94-101.

Taşlıdere, E., \& Eryılmaz, A. (2009). Alternative to traditional physics instruction: Effectiveness of conceptual physics approach. Eurasian Journal of Educational Research, 35, 109-128.

Taşlıdere, E. (2014). Kavramsal değişim yaklaşımının doğru akım devreleri konusundaki kavram yanılgılarının giderilmesine etkisi. Bartın Üniversitesi Eğitim Fakültesi Dergisi, 3(1), 200-223.

Temiz, B. K., \& Tan, M. (2009). Lise 1. sınıf öğrencilerinin değişkenleri belirleme ve hipotez kurma becerileri. Kastamonu Ĕgitim Dergisi, 17(1), 195-202.

Tsai, C-C. (1999). Overcoming junior high school students' misconceptions about microscopic views of phase change: A study of an analogy activity. Journal of Science Education and Technology, 8(1), 83-91.

Wichaidit, S., Wongyounoi, S., Dechsri, P., \& Chaivisuthangkura, P. (2011). Using analogy and model to enhance conceptual change in Thai middle school students. US-China Education Review, 8(3), 333-338.

Yıldırım, H. İ., Yalçın, N., Şensoy, Ö., \& Akçay, S. (2008). İlköğretim 6., 7. ve 8. sınıf öğrencilerinin elektrik akımı konusunda sahip oldukları kavram yanılgıları. Kastamonu Eğitim Dergisi, 16(1), 67-82.

Yıldırım, A., \& Şimşek, H. (2011). Sosyal bilimlerde nitel araştırma yöntemleri (8. Bask1). Ankara: Seçkin Yayıncılık.

Yılmaz, H., \& Huyugüzel-Çavaş, P. (2006). 4-E öğrenme döngüsü yönteminin öğrencilerin elektrik konusunu anlamalarına olan etkisi. Türk Fen Eğitimi Dergisi, 3(1), 2-18.

Yumuşak, A. (2008). Fen bilgisi öğretmen adaylarının 1sı-sıcaklık, mekanik ve elektrik konularındaki kavram yanılgıları ve nedenlerinin araştırılması (CBÜ örneği). Milli Ĕ̈itim, 180, 123-132. 